\title{
An efficient workflow to accurately compute groundwater recharge for the study of rainfall-triggered deep-seated landslides, application to the Séchilienne unstable slope (western Alps)
}

\author{
A. Vallet, C. Bertrand, O. Fabbri, and J. Mudry \\ UMR6249 - Chrono-Environnement, Université de Franche-Comté, 16 route de Gray, 25030 Besançon CEDEX, France \\ Correspondence to: A. Vallet (aurelien.vallet@univ-fcomte.fr)
}

Received: 15 May 2014 - Published in Hydrol. Earth Syst. Sci. Discuss.: 16 June 2014

Revised: 17 October 2014 - Accepted: 12 November 2014 - Published: 22 January 2015

\begin{abstract}
Pore water pressure build-up by recharge of underground hydrosystems is one of the main triggering factors of deep-seated landslides. In most deep-seated landslides, pore water pressure data are not available since piezometers, if any, have a very short lifespan because of slope movements. As a consequence, indirect parameters, such as the calculated recharge, are the only data which enable understanding landslide hydrodynamic behaviour. However, in landslide studies, methods and recharge-area parameters used to determine the groundwater recharge are rarely detailed. In this study, the groundwater recharge is estimated with a soil-water balance based on characterisation of evapotranspiration and parameters characterising the recharge area (soil available water capacity, runoff and vegetation coefficient). A workflow to compute daily groundwater recharge is developed. This workflow requires the records of precipitation, air temperature, relative humidity, solar radiation and wind speed within or close to the landslide area. The determination of the parameters of the recharge area is based on a spatial analysis requiring field observations and spatial data sets (digital elevation models, aerial photographs and geological maps). This study demonstrates that the performance of the correlation with landslide displacement velocity data is significantly improved using the recharge estimated with the proposed workflow. The coefficient of determination obtained with the recharge estimated with the proposed workflow is $78 \%$ higher on average than that obtained with precipitation, and is $38 \%$ higher on average than that obtained with recharge computed with a commonly used simplification in landslide studies (recharge $=$ precipitation minus non-calibrated evapotranspiration method).
\end{abstract}

\section{Introduction}

Pore water pressure build-up by recharge of aquifers is one of the main triggering factors of destabilisation of deep-seated landslides (Noverraz et al., 1998; Van Asch et al., 1999; Guglielmi et al., 2005; Bogaard et al., 2007; Bonzanigo et al., 2007). In most deep-seated landslides, pore water pressure data are not available since piezometers, if any, have a very short lifespan because of slope movements. In addition, landslides show heterogeneous, anisotropic and discontinuous properties (Cappa et al., 2004; Binet et al., 2007a) and local measurements are rarely representative of the overall behaviour of the landslide aquifers. In the absence of piezometric measurements, the groundwater recharge is used as the most relevant parameter to characterise the pore water pressure of the landslide aquifers. Groundwater recharge (hereafter recharge), also referred to as deep percolation, is the part of the precipitation which recharges the saturated zones (aquifers).

Landslide studies involve a wide range of specialities (subsurface geophysics, structural geology, modelling, geotechnics, and geomechanics). Scientists or engineers in charge of landslides may not have the required hydrology knowledge to accurately estimate the recharge. In most cases, deep-seated landslide studies devoted to characterise the rainfall-destabilisation relationships do not take into account recharge with enough accuracy. In particular, some studies estimate the recharge without calibration of the evapotranspiration estimation methods and without soil-water balance (Canuti et al., 1985; Alfonsi, 1997; Hong et al., 2005; Binet et al., 2007b; Durville et al., 2009; Pisani et al., 2010; Prokešová et al., 2013). Lastly, several studies use precipita- 
tion data instead of the recharge (Rochet et al., 1994; Zêzere et al., 2005; Meric et al., 2006; Helmstetter and Garambois, 2010; Belle et al., 2014). These approaches can overestimate the groundwater recharge and can thus bias the characterisation of the relationship between rainfall and destabilisation. A more accurate estimation of the groundwater recharge signal can improve the accuracy of these studies. So far, no computation workflow has been proposed to estimate simply and accurately the recharge in the context of landslide studies.

Patwardhan et al. (1990) showed that the soil-water balance method is an accurate way to estimate groundwater recharge. Recharge computation with a soil-water balance depends mainly on the surface runoff, the soil available water capacity (SAWC) and the specific vegetation (so-called crop) evapotranspiration $\left(\mathrm{ET}_{\mathrm{c}}\right.$, also referred to as potential evapotranspiration), itself being deduced from reference vegetation evapotranspiration $\left(\mathrm{ET}_{0}\right)$ with a vegetation coefficient $\left(K_{\mathrm{c}}\right)$. The Penman-Monteith method (Eq. A6 in Appendix A), hereafter referred to as the $\mathrm{ET}_{0}$ standard equation or FAO-56 PM, developed in the paper FAO-56 (Food and Agriculture Organization of the United Nations) is considered by the scientific community as a global standard method to estimate $\mathrm{ET}_{0}$ worldwide (Jensen et al., 1990; Allen et al., 1998). This method requires the knowledge of the air relative humidity, the air temperature, the wind speed and the solar radiation. However, most weather stations in landslide areas record only air temperature and rainfall. Unlike the FAO-56 PM method, methods based only on air temperature and solar radiation $\left(R_{\mathrm{S}}\right)$ allow for a simpler expression of $\mathrm{ET}_{0}$ (Tabari et al., 2013). Besides, $R_{\mathrm{S}}$ can also be estimated only from air temperature (Almorox, 2011), thus allowing $\mathrm{ET}_{0}$ to be obtained only from air temperature records. These reducedset methods are developed under specific site conditions and must be calibrated in order to improve accuracy (Allen et al., 1994; Shahidian et al., 2012).

The objective of this study is to develop a parsimonious, yet robust, guideline workflow to calculate time series of groundwater recharge at the scale of the recharge area, time series that can subsequently be used as a deterministic variable in landslide studies. To maximise the accessibility to various user groups, we strive to develop an efficient method, balancing technical accuracy with operational simplicity. The proposed workflow is applied on the deepseated Séchilienne landslide. To test its reliability, a correlation analysis is used to evaluate whether the calculated groundwater recharge is more strongly correlated with measured land mass displacement velocities than with precipitation or with recharge estimated with a common simplification in landslide studies (recharge $=$ precipitation minus non-calibrated $\mathrm{ET}_{0}$ (Canuti et al., 1985; Binet et al., 2007b; Pisani et al., 2010; Prokešová et al., 2013). The significance of the correlations is assessed with bootstrap tests. The proposed study aims at showing that an accurate estimation of the recharge can significantly improve the results of rainfalldisplacement studies.

\section{Method}

\subsection{General workflow}

In the case of deep-seated landslides triggered by deep watersaturated zones, the impact of a multiday cumulative rainfall is far more significant than rainfall duration or intensity (Van Asch et al., 1999; Guzzetti et al., 2008). For these reasons, the workflow is developed to compute daily groundwater recharge. Similarly, this study is based on displacement recorded at a daily time step. For the sake of simplicity, the daily displacement, equivalent to a velocity measurement in millimetres per day, is hereafter referred to as displacement. The groundwater recharge is estimated with a soilwater balance based on characterisation of $\mathrm{ET}_{0}$ and parameters characterising the recharge area (SAWC, runoff and $K_{\mathrm{c}}$ ). The computation workflow (Fig. 1), hereafter referred to as LRIW (Landslide Recharge Input Workflow), includes four steps.

The estimation of the $\mathrm{ET}_{0}$ requires the records of air temperature within the landslide area and relative humidity, solar radiation and wind speed within or close to the landslide area. In the case of a landslide-located weather station recording only the temperature, the first step (detailed in Sect. 2.2) consists of a regional calibration of $\mathrm{ET}_{0}$ and $R_{\mathrm{S}}$ reduced-set equations (equations detailed in Appendix A). The calibrated methods then allow estimating evapotranspiration based only on temperature records. In the case of a landslide weather station recording the full set of parameters, the first step can be skipped and the FAO-56 PM method can then be used to estimate $\mathrm{ET}_{0}$. The second step (detailed in Sect. 2.3) consists in estimating the recharge-area parameters (surface runoff, SAWC and $K_{\mathrm{c}}$ ) using a GIS (geographic information systems) composite method requiring field observations and spatial data sets (digital elevation models (DEMs), aerial photographs and geological maps). The third step (detailed in Sect. 2.4) uses a soil-water balance to estimate the recharge with the estimated $\mathrm{ET}_{0}$ and the estimation of the recharge-area parameters. The fourth step (detailed in Sect. 2.5) consists of a sensitivity analysis based on a recharge-displacement velocity correlation and is performed in order to refine the estimations of SAWC and runoff coefficient.

\subsection{Step 1: regional calibration of $\mathrm{ET}_{0}$ and $\boldsymbol{R}_{\mathrm{S}}$ methods}

$\mathrm{ET}_{0}$ reduced-set and $R_{\mathrm{S}}$ temperature methods were initially developed for given regions or sites with their own climatic conditions and must be calibrated to take into account the weather conditions of the study site. Details about calibration can be found in the literature (Allen et al., 1994; Itenfisu et al., 2003; Lu et al., 2005; Alkaeed et al., 2006; Alexandris et al., 2008; Shahidian et al., 2012; Tabari et al., 2013).

The regional calibration method (step 1; Fig. 1) is performed using the records of nearby weather stations (here- 




Figure 1. LRIW diagram. Step 1: calibration of standard $\mathrm{ET}_{0}$ and $R_{\mathrm{S}}$ methods. Step 2: estimation of recharge-area parameters required for the soil-water balance $\left(R_{\text {coeff }}, K_{\mathrm{c}}\right.$ and SAWC) and the infiltration structures. Step 3: computation of the recharge with the soil-water balance. * In the case of a landslide-located weather station recording the full set of parameters, the first step can be skipped and the ET 0 of step 3 can be estimated directly at the study site with the standard $\mathrm{ET}_{0}$ method (FAO-56 PM method).

after referred to as reference weather stations) having similar climatic conditions as the study site and recording the required meteorological parameters. The calibration of $R_{\mathrm{S}}$ and $\mathrm{ET}_{0}$ methods are performed for each reference weather station (local scale). The local adjustment coefficients of the reference stations are then averaged in order to define a regional calibration. The user has to maintain a balance between the number of selected reference stations and the necessity for these stations to be located in areas with climatic conditions similar to those of the study site. For sites with a sparse weather station network, one reference station can be sufficient for the calibration, provided that this station has the same weather conditions as those of the studied site.

The performance assessment of regional-scale calibrated methods is based on the comparison between observed measurements and calibrated estimates for $R_{\mathrm{S}}$ and between FAO$56 \mathrm{PM}$ estimates and calibrated estimates for $\mathrm{ET}_{0}$ for each reference weather station. Performance indicators are the coefficient of determination $\left(R^{2}\right)$, the slope and the intercept from linear regression (independent variable: estimated pa- 
rameter; dependant variable: reference parameter), and the root mean square error (RMSE).

\subsubsection{Solar radiation methods}

Bristow and Campbell (1984) and Hargreaves and Samani (1985) proposed methods to compute $R_{\mathrm{S}}$ based solely on the air temperature measurement (Eqs. A1 and A2 in Appendix A). Castellvi (2001) demonstrated that both methods show good results for daily frequencies. The coefficients of the Bristow-Campbell method have to be evaluated. The coefficients of the Hargreaves-Samani method have default values. However, Trajkovic (2007) showed that the regional calibration of the Hargreaves-Samani method is significantly improved by an adjustment of the coefficients rather than by a linear regression. Therefore, all the $\mathrm{HS}_{\text {mod }} R_{\mathrm{s}}$ coefficients are adjusted. In this study, modified forms of the Bristow-Campbell method (Eq. A3) and Hargreaves-Samani method (Eq. A4) are used. For the $R_{\mathrm{S}}$ equations, the adjustment of the local calibration coefficients is non-linear. To adjust the calibration coefficients, a grid search iterative algorithm is used to maximise the $R^{2}$ value while minimising the RMSE at each reference weather station.

\subsubsection{Evapotranspiration methods}

$\mathrm{ET}_{0}$ is the evapotranspiration from a reference grass surface and is used as a standard from which $\mathrm{ET}_{\mathrm{c}}$ is deduced as follows (Allen et al., 1998):

$\mathrm{ET}_{\mathrm{c}}=\mathrm{ET}_{0} \times K_{\mathrm{c}}$,

where $K_{\mathrm{c}}$ is the vegetation coefficient.

Several $\mathrm{ET}_{0}$ methods using a reduced data set in comparison to the FAO-56 PM method have been developed worldwide. Only a few methods are commonly used. This is the case with the five $\mathrm{ET}_{0}$ methods selected for this study, which have shown good performance when using daily to weekly frequencies (Trajkovic, 2005; Yoder et al., 2005; Alexandris et al., 2008; Shahidian et al., 2012; Tabari et al., 2013). The five selected $\mathrm{ET}_{0}$ methods, namely the methods of Hargreaves and Samani (1985), Makkink (1957), Turc (1961), Priestley and Taylor (1972), and the Penman-Monteith reduced-set method (Allen et al., 1998), require records of $R_{\mathrm{S}}$ and temperature (Eqs. A7-A12 in Appendix A). As $R_{\mathrm{S}}$ can be estimated with a calibrated $R_{\mathrm{S}}$ temperature-based method, $\mathrm{ET}_{0}$ can thus be obtained with temperature records only.

$\mathrm{ET}_{0}$ is calculated using data collected at each reference weather station (independent $\mathrm{ET}_{0}$ estimates). These calculations follow the FAO-56 PM method outlined in the FAO-56 document (Allen et al., 1998). These independent ET $_{0}$ estimates are then used as pseudo-standards for the purpose of calibrating the regional-scale $\mathrm{ET}_{0}$ methods. A linear regression is performed for each of the evapotranspiration methods and for each reference weather station (Eq. 2). The slope $a$ and the intercept $b$ of the best-fit regression line are used as local calibration coefficients.

$\mathrm{ET}_{0 \mathrm{FAO}-56 \mathrm{PM}}=a \mathrm{ET}_{0 \text { method }}+b$,

where $\mathrm{ET}_{0 \mathrm{FAO}} 56 \mathrm{PM}$ is the $\mathrm{ET}_{0}$ estimated with the standard method and $\mathrm{ET}_{0 \text { method }}$ is the $\mathrm{ET}_{0}$ obtained by any of the five methods tested in this study. The linear regression method has been widely used to calibrate $\mathrm{ET}_{0}$ methods (Allen et al., 1994; Trajkovic, 2005; Shahidian et al., 2012).

\subsection{Step 2: estimation of the parameters of the recharge area}

The estimation of the recharge with the soil-water balance (step 3; Sect. 2.4) requires the calculation, at the scale of the recharge area, of three parameters which are SAWC, runoff

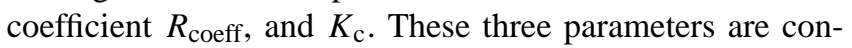
trolled by one or several factors which are, in this study, the slope gradient, the geological nature of the substratum and the type of vegetation cover. Moreover, at the scale of the recharge area, the controlling factors are commonly heterogeneous and thus the recharge-area parameters cannot be readily computed. For each of the controlling factors, the recharge area is divided into subareas (hereafter referred to as factor subareas) characterised by homogenous factor properties. Factor subareas can be either continuous or discontinuous, and their number and shape can differ, depending of the spatial distribution of the factors. Relevant factor subareas are in turn used to define parameter subareas. For a given parameter subarea, the value of the parameter is estimated from either field measurements or from the literature. The parameter values at the scale of the recharge area are then calculated by taking into account the relative surface of the parameter subareas (step 2; Fig. 1). Lastly, if preferential infiltration structures (hereafter referred to as infiltration structures) such as sinkholes, cracks, reverse slope areas, bare ground or any topographical depression which can collect the surface runoff are present in the recharge area, the above-mentioned parameters have to be adjusted. For such areas, the SAWC

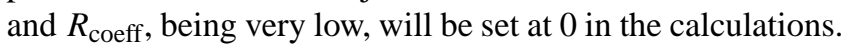
Similarly, for such areas, $\mathrm{ET}_{0}$ is negligible and therefore the surface of these areas is disregarded for the $K_{\mathrm{c}}$ computation. The parameter values are afterwards refined by a sensitivity analysis (step 4; Sect. 2.5) in order to find the optimal set of recharge-area parameters.

The $K_{\mathrm{c}}$ parameter takes into account four key characteristics (vegetation height, albedo, canopy resistance and evaporation from soil) that distinguish the vegetation type of a given subarea from the reference grass used to estimate $\mathrm{ET}_{0}$ (Allen et al., 1998). The $K_{\mathrm{c}}$ subareas are defined according to the type of vegetation (e.g. meadows and forests) obtained from aerial photographs. The dominant vegetation species assigned to each vegetation type can be obtained from the literature (e.g. forest agency data) or from field observations. Since the $K_{\mathrm{c}}$ parameter depends on the stage of development 
of the vegetation, it varies from a minimum value during winter to a maximum value during summer. The minimum and maximum $K_{\mathrm{c}}$ values are estimated from the literature and are assigned respectively to 4 February (middle of winter) and 6 August (middle of summer) of each year. A daily linear interpolation is performed for $K_{\mathrm{c}}$ between these two dates (Verstraeten et al., 2005).

The SAWC parameter refers to the difference between a maximum water content above which all free water is drained through gravity (field capacity) and a minimum moisture content below which plant roots cannot extract any water (permanent wilting point). The SAWC is mainly affected by soil texture and thickness, both depending primarily on the geological substratum and the vegetation. The SAWC subareas are defined according to the type of vegetation (obtained from aerial photographs) and to the geological substratum (obtained from geological maps). SAWC values can be either calculated with pedotransfer functions (Bruand et al., 2004; Pachepsky and Rawls, 2004) from soil properties (type of horizon, texture and bulk density) and thickness or obtained directly from the literature. Soil properties and thickness can be obtained from the literature (e.g. pedological maps), from morphological description or laboratory measurements of auger hole cores.

The method used to estimate the surface runoff is similar to the commonly used "runoff rational method". The $R_{\text {coeff }}$ parameter depends mainly on topography and vegetation. The $R_{\text {coeff }}$ subareas are defined according to the vegetation (obtained from aerial photographs). An average slope gradient obtained from the DEM is assigned to each vegetation subarea. The $R_{\text {coeff }}$ values can then be calculated from vegetation cover and slope gradient through the use of charts such as the Sautier chart (Musy and Higy, 2011).

Infiltration structures are first located through examination of aerial photographs (lineament analysis) and geological maps, and then inspected in the field.

\subsection{Step 3: recharge computation with soil-water balance}

The soil-water balance workflow used to estimate the recharge at a daily frequency is detailed in Fig. 2. All terms required for the soil-water balance estimation are expressed in water amount (millimetres), except for $R_{\text {coeff }}$ expressed in percentage. The soil-water balance is based on $\mathrm{ET}_{\mathrm{c}}, \mathrm{SAWC}$, $K_{\mathrm{c}}$ and $R_{\text {coeff. }}$. The precipitation $(P)$ is the amount of liquid (rain) or solid (snow) water which falls on the recharge area. The precipitation will be taken here as the sum of snowmelt and rainfall. A part of this water amount is intercepted by the vegetative canopy (interception; Fig. 2a). The remainder of precipitation reaches the ground surface and forms (i) the runoff (Rf), which is the water joining the surface drainage network and (ii) the infiltration $(I)$ into the soil layer which supplies the SAWC. The remaining part of the precipitation not taken-up by evapotranspiration and runoff and not stored in the SAWC is called the recharge $(R)$. It corresponds to deep percolation and is the component of the precipitation which recharges the saturated zone (Fig. 2a).

The $\mathrm{ET}_{\mathrm{c}}$ is a lumped parameter including potential transpiration, potential soil evaporation and canopy interception evaporation (Verstraeten et al., 2005). In the proposed computation diagram workflow (Fig. 2b) the interception component is therefore integrated in the $\mathrm{ET}_{\mathrm{c}}$ component. The $\mathrm{ET}_{\mathrm{c}}$ is the water evapotranspired without any other restrictions than the atmospheric demand (assuming unlimited soil water availability). However, field conditions do not always fulfil these requirements, particularly during low rainfall periods when water supplies are inadequate to support vegetation uptakes. The actual evapotranspiration $\left(\mathrm{ET}_{\mathrm{a}}\right)$ corresponds to the actual amount of evapotranspired water.

Runoff takes place when the intensity of a precipitation event exceeds the soil infiltration capacity. The use of a daily measurement frequency for precipitation does not allow for an accurate estimation of rainfall intensity. Instead, a $R_{\text {coeff }}$ is applied only for days when precipitation is greater than the average. Such days are considered as high intensity rainfall days. The $R_{\text {coeff }}$ is applied only to excess precipitation, after the demands of evapotranspiration and SAWC are met, i.e. when SAWC is fulfilled (Fig. 2b).

\subsection{Step 4: sensitivity analysis of the recharge-area parameters}

In the landslide recharge area, recharge can be considered as spatially heterogeneous. Indeed, in fractured rocks, the groundwater flow is mainly driven by an anisotropic fracture network. The proportion of infiltrated water which flows toward the landslide aquifer can significantly differ between two zones of the recharge area. Nevertheless, the GIS composite method considers that any part of the recharge area has the same weight with respect to the groundwater which flows toward the landslide aquifer. This homogeneous recharge assumption can lead to biased estimations of the recharge-area parameters. However, uncertainties in the delimitation of the recharge area can also lead to biased estimations.

A sensitivity analysis evaluates the possible overestimation or underestimation of the set of recharge-area parameters. The infiltration-structure subareas are used as fitting factors (varying from 0 to $100 \%$ of the recharge area surface) to adjust the estimation of the set of recharge-area parameters. A variation of the infiltration structure percentage corresponds to a variation of the contribution weight of the infiltration structures to the recharge of the landslide aquifer. Consequently, a variation of the infiltration structure percentage does not affect the relative proportion of the other subarea surfaces but only their contribution weights. The sensitivity analysis is based on the performance of a linear correlation between daily time series of recharge and displacement. The landslide displacement triggered by pore water pressure is therefore related to the hydrodynamic variations 


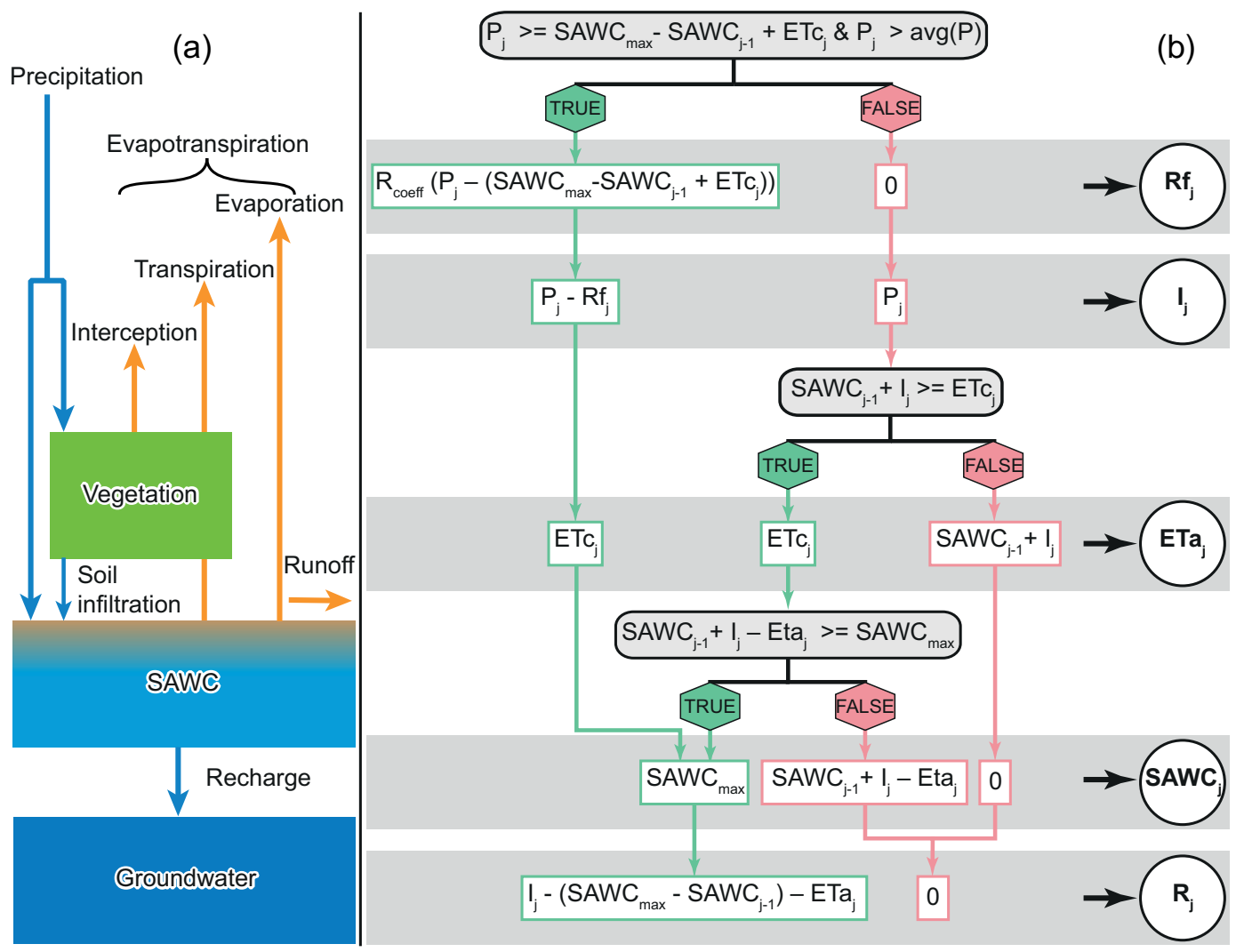

Figure 2. Soil-water balance: (a) soil-water balance conceptual representation and (b) soil-water balance diagram used for recharge computation on a daily frequency. SAWC: soil available water capacity; $\mathrm{SAWC}_{\max }$ : $\mathrm{SAWC}$ threshold (possible maximum); $P$ : precipitation (rainfall + snowmelt); avg $(P)$ : precipitation average of the entire record; $I$ : part of precipitation which infiltrates the soil; Rf: surface runoff; $R_{\text {coeff }}$ : runoff coefficient; $\mathrm{ET}_{\mathrm{c}}$ : specific vegetation evapotranspiration; $\mathrm{ET}_{\mathrm{a}}$ : actual vegetation evapotranspiration; $R$ : recharge. Units: mil-

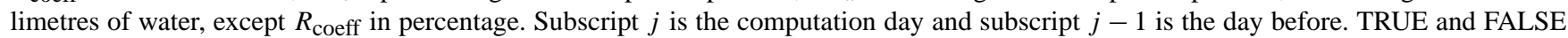
are the answers of the conditional inequality statements.

of the landslide aquifers. For this reason, the performance of the correlation between recharge and displacement informs whether the recharge-area parameters are satisfactorily estimated. The sensitivity analysis allows determining the optimal set of recharge-area parameters which maximise the performance of the correlation.

\subsection{Correlation between water input and displacement}

\subsubsection{Antecedent cumulative sum}

The correlation between water input and displacement requires measurements of landslide displacements at the same temporal frequency (daily frequency in this study) as the measurements of water input (precipitation or recharge). The groundwater hydrodynamic processes in aquifers are nonlinear. A former rainfall event displays less impact (though not negligible) than a recent one on the aquifer hydrodynamic fluctuations (Canuti et al., 1985; Crozier, 1986; Diodato et al., 2014). The daily precipitation/recharge time series cannot therefore be used without appropriate corrections. An an- tecedent cumulative sum of precipitation/recharge weighted by a factor $\alpha$ is applied as a moving window to the daily precipitation/recharge time series (Eq. 3). The antecedent cumulative sum allows approximating the daily triggering impact of the aquifer (ATI) on the landslide destabilisation. In order to take into account the groundwater transit time, a $\beta$ time-lag factor is introduced. This factor can shift the moving window from the target date $t$.

$\mathrm{ATI}_{\mathrm{t}}=\sum_{i=t+\beta}^{t+\beta+n} \frac{W_{\mathrm{i}}}{1+\alpha(i-(t+\beta))}$,

where $\mathrm{ATI}_{\mathrm{t}}$ is the aquifer triggering impact (in mm) at the date $t ; \beta$ is the time shift of the moving window (in days); $i$ is the $i$ th day from the date $t(i=t+\beta$ : start of the moving window and $i=t+\beta+n$ : end of the moving window); $n$ is the length of the moving window of the cumulative period (in days); $W_{\mathrm{i}}$ water input, i.e. precipitation or recharge at the $i$ th day (in $\mathrm{mm}$ ), and $\alpha$ is the weighting factor.

An iterative grid search algorithm is used to find the optimal set of parameters of the antecedent cumulative sum. 
The optimal set of parameters is the set that maximises the correlation performance itself based on the $R^{2}$ indicator. The grid search algorithm investigates the following parameter ranges: $\mathrm{n}$ from 1 to 250 days (increment: 1 day), $\alpha$ from 0 to 0.5 (increment: 0.0001 ) and $\beta$ from 1 to 10 days (increment: 1 day).

\subsubsection{Significance of the water input-displacement correlation}

The bootstrap method, which is an inference statistical resampling method, is used to estimate the confidence interval (CI) of estimated parameters and to perform statistical hypothesis tests (Chernick, 2008). The bootstrap method uses resampling with replacement and preserves the pair-wise relationship. However, for interdependent data (such as time series), the structure of the data set has to be preserved during the resampling. The moving block bootstrap is a variant of the bootstrap method. It divides data into blocks for which the structure is kept (Cordeiro and Neves, 2006). The moving block bootstrap method is performed with a 90-day block size (season) and 50000 iterations for each run.

To estimate the significance of the linear regression, the lower bound of the confidence interval (LBCI) of $R^{2}$ is used at the level of confidence of $90 \%$ (equivalent to a one-tailed test at the significance level of $5 \%$ ). An LBCI value greater than 0 means that the relationship is significant. Particular to statistical hypothesis tests is the definition of the tested null hypothesis which is often a default position opposite to the aim of the test, i.e. by stating that "there is no relationship between the two considered quantities". The null hypothesis is assumed to be true until it is rejected by statistical evidence in favour of the alternative opposite hypothesis. The recharge estimated with the LRIW workflow is hereafter

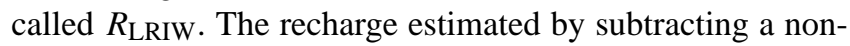
calibrated $\mathrm{ET}_{0}$ from precipitation is hereafter called $R_{\mathrm{PMNE}}$, PMNE standing for precipitation minus non-calibrated $\mathrm{ET}_{0}$.

To estimate whether the $R_{\mathrm{PMNE}}-$ displacement correlation $R^{2}$ is significantly better than the precipitation-displacement correlation $R^{2}$ value, the Null Hypothesis 1 (NH1) is tested. The NH1 states that the $R_{\mathrm{PMNE}}-$ displacement correlation $R^{2}$ value is not significantly greater than the $R^{2}$ value obtained from precipitation. In other words, the NH1 statistic test is the difference between the $R_{\mathrm{PMNE}} R^{2}$ value and the precipitation $R^{2}$ value, expected to be 0 if no difference. Similarly, the Null Hypothesis 2 (NH2) and the Null Hypothesis 3 (NH3) are tested. $\mathrm{NH} 2$ estimates whether the $R_{\mathrm{LRIW}}$-displacement correlation $R^{2}$ is significantly better than the precipitationdisplacement correlation $R^{2}$ value. NH3 estimates whether

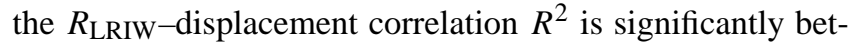
ter than the $R_{\mathrm{PMNE}}$-displacement correlation $R^{2}$ value.

To estimate whether the best precipitation- $R_{\text {LRIW- }}$ displacement correlation $R^{2}$ value computed from the sensitivity analysis is significantly better than the other $R^{2}$ values obtained, the Null Hypothesis 4 (NH4) is tested. The NH4 states that the best $R^{2}$ value is not significantly greater than the ones obtained with all the remaining combinations. In other words, the NH4 statistic test is the difference between the best $R^{2}$ value and the $R^{2}$ values obtained with the remaining combinations, expected to be 0 if no difference.

For all null hypotheses, the decision of rejection is made by determining how much of the bootstrap distribution (among 50000 iterations) falls below 0 by using the LBCI at the level of confidence of $90 \%$, equivalent to a one-tailed test at the significance level of $5 \%$. An LBCI value greater than 0 allows rejecting the null hypotheses.

\section{Application to the Séchilienne landslide}

\subsection{Geological settings and rainfall triggering}

The Séchilienne landslide is located in the French Alps on the right bank of the Romanche River, on the southern slope of the Mont Sec Massif (Fig. 3). The climate is mountainous with a mean annual precipitation of $1200 \mathrm{~mm}$. The geological nature of the area is composed of vertical N-S foliated mica schists unconformably covered by carboniferous to Liassic sedimentary deposits along the massif ridge line above the unstable zone. Quaternary glacio-fluvial deposits are also present. The Séchilienne landslide is limited eastwards by a $\mathrm{N}-\mathrm{S}$ fault scarp and northwards by a major head scarp of several hundred metres wide and tens of metres high below the Mont Sec. The slope is cut by a dense network of two sets of near-vertical open fractures trending N110-N120 and N70 (Le Roux et al., 2011).

The Séchilienne landslide is characterised by a deep progressive deformation controlled by the network of faults and fractures. A particularity of the Séchilienne landslide is the absence of a well-defined basal sliding surface. The landslide is affected by a deeply rooted (about 100-150 m) toppling movement of the $50-70^{\circ} \mathrm{N}$ slabs to the valley (accumulation zone) coupled with the sagging of the upper slope (depletion zone) beneath the Mont Sec (Vengeon, 1998; Durville et al., 2009; Lebrouc et al., 2013). A very active moving zone is distinguishable from the unstable slope where high displacement velocities can be 10 times higher than the rest of the landslide.

The landslide shows a higher hydraulic conductivity than the underlying stable bedrock (Vengeon, 1998; Meric et al., 2005; Le Roux et al., 2011), thus leading to a landslide perched aquifer (Guglielmi et al., 2002). The recharge of the landslide perched aquifer is essentially local, enhanced by the trenches and the counterscarps which tend to limit the runoff and to facilitate groundwater infiltration in the landslide area. However, the hydrochemical analyses of Guglielmi et al. (2002) show that the sedimentary deposits distributed above the landslide hold a perched aquifer which can recharge the landslide perched aquifer. The fractured metamorphic bedrock beneath the landslide contains a 


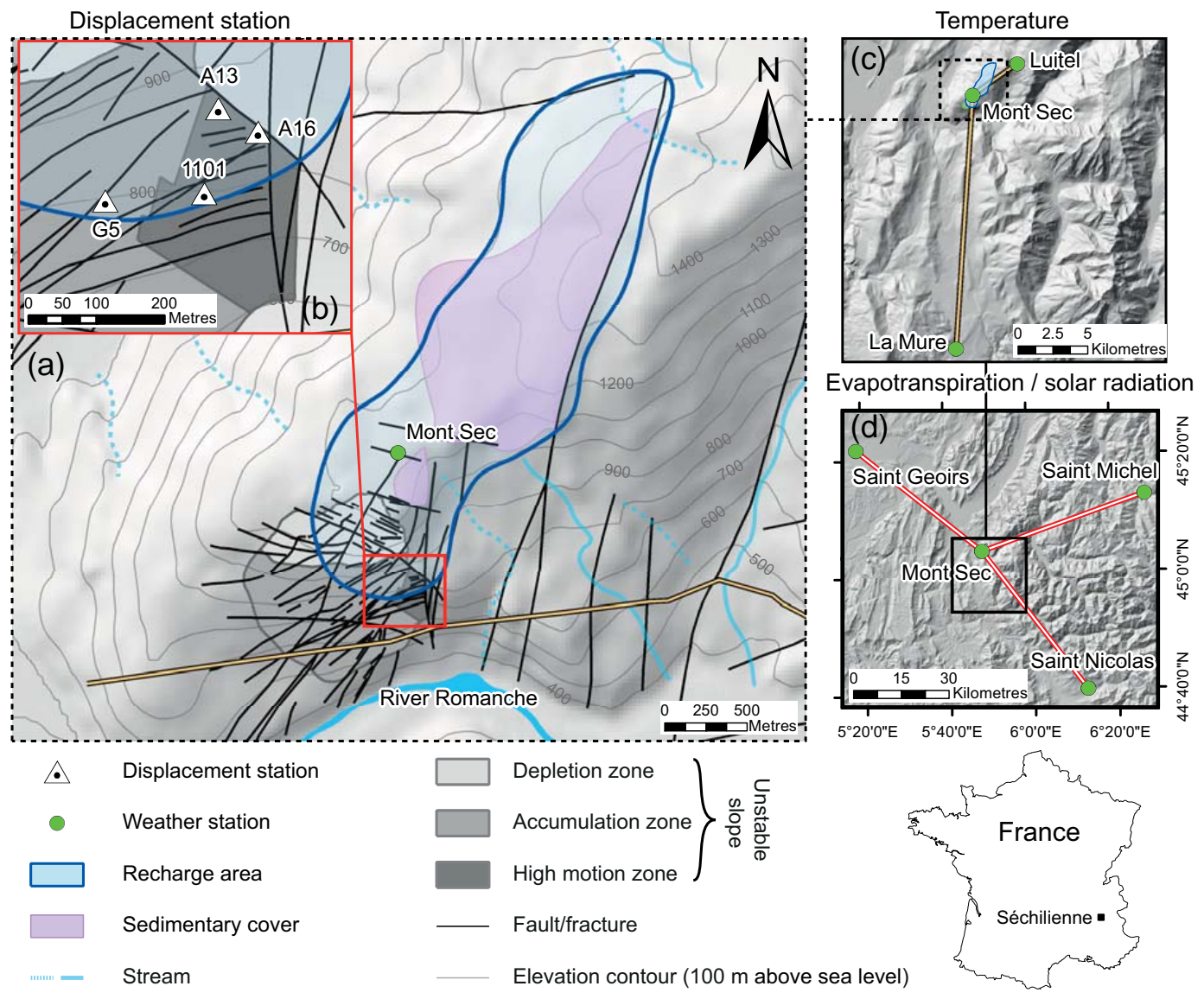

Figure 3. Location map of the Séchilienne landslide. (a) Map of the Séchilienne unstable slope and recharge area with the Mont Sec weather station. (b) Enlarged map of the most active area showing displacement stations. (c) Map showing the weather stations used for the temperature estimation at Mont Sec. (d) Map showing the weather stations used for evapotranspiration and solar radiation method calibration.

deep saturated zone at the base of the slope and an overlying vadose zone. The groundwater flow of the entire massif is mainly controlled by the network of fractures with high flow velocities (up to a few kilometres per day; Mudry and Etievant, 2007). The hydromechanical study of Cappa et al. (2014) shows that the deep aquifer can also trigger the Séchilienne landslide destabilisation as a result of stress transfer and frictional weakening. Thus, the Séchilienne landslide destabilisation is likely triggered by a twolayer hydrosystem: the landslide perched aquifer and the deep aquifer. The Séchilienne landslide behaviour is characterised by a good correlation between precipitations and displacement velocities (Rochet et al., 1994; Alfonsi, 1997; Durville et al., 2009; Chanut et al., 2013).The seasonal variations of the daily displacements are clearly linked to the seasonal variations of the recharge (high displacements during high flow periods and low displacements during low flow periods).

\subsection{Method implementation}

The recharge computation uses the daily rainfall recorded at the weather station located at Mont Sec, a few hundred metres above the top of the landslide (Table 1, Fig. 3). This station is equipped with rain and snow gauges and a temperature sensor. However, the temperature measurements at the Mont Sec station are considered unreliable because of a non-standard setting of the temperature sensor and numerous missing data. Consequently, the temperature at the Mont Sec station has to be estimated in order to estimate the evapotranspiration at the landslide site (see details about the computation in Appendix B).

Since the Mont Sec station does not record the full set of parameters (relative humidity, temperature, wind speed and solar radiation), a regional calibration of $\mathrm{ET}_{0}$ and $R_{\mathrm{S}}$ reduced-set methods is required. Three weather stations located at less than $60 \mathrm{~km}$ from the studied site are used as reference weather stations: Grenoble-Saint-Geoirs, Saint-JeanSaint-Nicolas and Saint-Michel-Maur (Table 1, Fig. 3). The Saint-Michel-Maur weather station does not measure $R_{\mathrm{S}}$, which is estimated with the Angström formula (Eq. A5 in 
Table 1. Summary of weather data sets with parameters used $(\mathrm{X})$ at the various locations. Distance is measured from the Séchilienne landslide, $R_{\mathrm{S}}$ is the solar radiation, $N$ is the sunshine duration, $W$ is the wind speed, $H$ is the humidity, $T$ is the temperature and $P$ is the precipitation depth.

\begin{tabular}{|c|c|c|c|c|c|c|c|c|c|c|c|}
\hline Station name & $\begin{array}{l}\text { Elevation } \\
\text { (m a.s.1.) }\end{array}$ & $\begin{array}{l}\text { Distance } \\
(\mathrm{km})\end{array}$ & From & To & $R_{\mathrm{S}}$ & $N$ & $W$ & $H$ & $T$ & $P$ & $\begin{array}{l}\text { Number } \\
\text { of days } \\
\text { with data }\end{array}$ \\
\hline Saint-Jean-Saint-Nicolas & 1210 & 55 & 1 Jan 2004 & 1 Jan 2012 & $\mathrm{X}$ & $X$ & $\mathrm{X}$ & $\mathrm{X}$ & $\mathrm{X}$ & & 2876 \\
\hline Saint-Michel-Maur & 698 & 54 & 1 Jan 2004 & 1 Jan 2012 & & $X$ & $\mathrm{X}$ & $\mathrm{X}$ & $\mathrm{X}$ & & 2864 \\
\hline Grenoble-Saint-Geoirs & 384 & 51 & 8 Jul 2009 & 1 Jan 2012 & $\mathrm{X}$ & $X$ & $\mathrm{X}$ & $\mathrm{X}$ & $\mathrm{X}$ & & 907 \\
\hline Chamrousse & 1730 & 9 & 12 Sep 2002 & 1 Mar 2012 & & & $\mathrm{X}$ & $\mathrm{X}$ & & & 3261 \\
\hline La Mure & 881 & 18 & 9 Sep 1992 & 1 Jan 2012 & & & & & $\mathrm{X}$ & & 7517 \\
\hline Luitel & 1277 & 4 & $6 \mathrm{Jul} 2006$ & 23 Jul 2012 & & & & & $\mathrm{X}$ & & 2193 \\
\hline Mont Sec & 1148 & 0.2 & 9 Sep 1992 & 1 Jan 2012 & & & & & & $\mathrm{X}$ & 7517 \\
\hline
\end{tabular}

Table 2. Statistics of the displacement records and results of the best linear correlation between precipitation/ $R_{\mathrm{LRIW}}$ and displacement records for four displacement stations (1101, A13, A16 and G5). The displacement column indicates basic statistics of the displacement records: first quartile $\left(Q_{1}\right)$, median and third quartile $\left(Q_{3}\right)$. Cumulative period $(n)$, shift factor $(\beta)$ and weighting factor $(\alpha)$ are the terms of Eq. (3). $P$ stands for precipitation, $R_{1}$ stands for $R_{\mathrm{PMNE}}$ and $R_{2}$ stands for $R_{\mathrm{LRIW}}$.

\begin{tabular}{|c|c|c|c|c|c|c|c|c|c|c|c|c|c|c|c|}
\hline \multirow[t]{2}{*}{ Station } & \multicolumn{3}{|c|}{$\begin{array}{l}\text { Displacement } \\
\text { mm day }^{-1}\end{array}$} & \multicolumn{3}{|c|}{$\begin{array}{l}\text { Cumulative } \\
\text { period }(n)\end{array}$} & \multicolumn{3}{|c|}{$\begin{array}{c}\text { Shift } \\
\text { factor }(\beta)\end{array}$} & \multicolumn{3}{|c|}{$\begin{array}{l}\text { Weighting factor } \\
\qquad(\alpha)\end{array}$} & \multicolumn{3}{|c|}{$R^{2}$} \\
\hline & $Q_{1}$ & median & $Q_{3}$ & $P$ & $R_{1}$ & $R_{2}$ & $P$ & $R_{1}$ & $R_{2}$ & $P$ & $R_{1}$ & $R_{2}$ & $P$ & $R_{1}$ & $R_{2}$ \\
\hline 1101 & 1.75 & 2.50 & 3.84 & 42 & 54 & 68 & 2 & 2 & 2 & 0.071 & 0.065 & 0.091 & 0.28 & 0.35 & 0.50 \\
\hline A13 & 1.18 & 1.75 & 3.41 & 52 & 80 & 82 & 3 & 2 & 2 & 0.102 & 0.070 & 0.091 & 0.28 & 0.37 & 0.52 \\
\hline A16 & 1.94 & 2.98 & 4.39 & 64 & 71 & 76 & 2 & 2 & 2 & 0.163 & 0.125 & 0.168 & 0.34 & 0.44 & 0.59 \\
\hline G5 & 0.02 & 0.05 & 0.08 & 8 & 169 & 132 & 0 & 6 & 6 & 0.039 & 0.003 & 0.011 & 0.001 & 0.08 & 0.24 \\
\hline
\end{tabular}

Appendix A) using sunshine duration data recorded at the station. The Angström formula empirical default coefficients are tuned with the two other weather stations $\left(a_{\mathrm{S}}=0.232\right.$ and $\left.b_{\mathrm{S}}=0.574\right)$.

The delimitation of the recharge area of the two-layer hydrosystem (Fig. 3) of the Séchilienne landslide is based on the geological and hydrochemical studies of Vengeon (1998), Guglielmi et al. (2002) and Mudry and Etievant (2007). The recharge area is delimited by the spatial extent of the sedimentary cover of which the hosting perched aquifer recharges the two-layer hydrosystem. Groundwater flow of the entire Mont Sec Massif is controlled by faults and fractures. The N20 fault bordering the sedimentary cover to the east as well as the $\mathrm{N}-\mathrm{S}$ fault zone bordering the landslide to the east are structures which delimitate the recharge area. The scarcity of information does not allow accurately defining the actual extent of the recharge area. The sensitivity analysis mentioned in Sect. 2.5 allows compensating for the possible biases introduced by this uncertainty. The following spatial data sets are used for the estimation of the parameters of the recharge area. The aerial photographs ( $0.5 \mathrm{~m}$ resolution) and a DEM of $25 \mathrm{~m}$ resolution are provided by the Institut National de l'Information Géographique et Forestière (IGN) and geological maps are provided by the French Geological Survey (BRGM).
The Séchilienne landslide is permanently monitored by a dense network of displacement stations managed by the CEREMA Lyon (Duranthon et al., 2003). In this study, one infrared station (1101) and three extensometer stations (A16, A13 and G5) are used. Stations 1101, A13 and A16 are representative of the most active zone (median displacements of $2.5,1.75$ and $2.98 \mathrm{~mm}$ day $^{-1}$, respectively), while G5 is located on a much less active zone (median displacement of $0.05 \mathrm{~mm} \mathrm{day}^{-1}$; Fig. 3, Table 2).

The sensitivity analysis is performed on the A16 extensometer on the period from 1 May 1994 to 1 January 2012, period during which both A16 extensometer and recharge data sets are available. The performance test of the LRIW workflow against precipitation and $R_{\mathrm{PMNE}}$ is performed on the four displacements station in the period from 1 January 2001 to 1 January 2012, period during which the four stations and recharge data sets are available. The $R_{\mathrm{PMNE}}$ is estimated with the non-calibrated Turc equation (Eq. A8) which is the most appropriate $\mathrm{ET}_{0}$ reduced-set equation for the Séchilienne site. Indeed, the Turc equation was developed initially for the climate of France. The Turc equation requires the estimation of $R_{\mathrm{S}}$ which is performed with the non-calibrated Hargreaves-Samani equation (Eq. A2). 


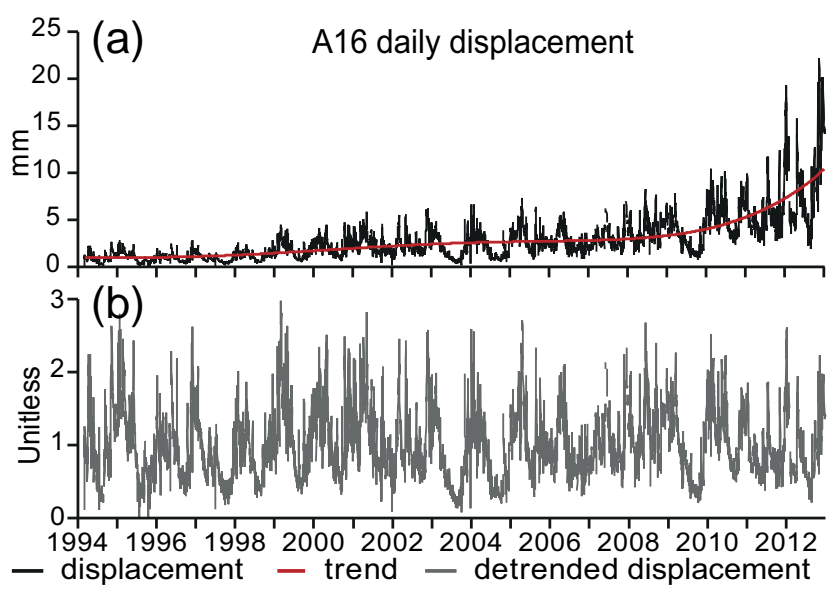

Figure 4. Trend removal of A16 extensometer displacement data. (a) A16 displacement data and the fourth-order polynomial curve fitting considered as the displacement trend; (b) A16 detrended data (unitless) corresponding to A16 displacement data for which the trend is removed by a multiplicative method.

\subsection{Displacement data detrending}

The long-term displacement monitoring shows that displacement rate and amplitude exponentially increased with time as illustrated by the records of extensometer A16 (Fig. 4a). The rainfall data series does not show any trend over the year, meaning that the displacement trend is independent of the recharge amount. Consequently, on the Séchilienne landslide, for the same amount of rainfall, the displacement rate and magnitude responses increase steadily with time. The observed trend is the consequence of a progressive weakening of the landslide due to long-term repetitive stresses. The accumulating deformation can be assimilated to long-term creep (Brückl, 2001; Bonzanigo et al., 2007) and can be explained by a decrease of the slope shear strength (Rutqvist and Stephansson, 2003). As shown by the detrended displacement, the Séchilienne landslide is constantly moving and shows large daily to seasonal variations which seem to be the landslide response to the precipitation trigger. Consequently, the precipitation-displacement correlation is performed on the detrended displacement.

The exponential trend is removed with the statistical multiplicative method $\left(y_{t}=T_{t} S_{t} I_{t}\right)$ where the time series $\left(y_{t}\right)$ is composed of three components (Madsen, 2007; Cowpertwait and Metcalfe, 2009; Aragon, 2011): trend $\left(T_{t}\right)$, seasonal $\left(S_{t}\right)$ and irregular $\left(I_{t}\right)$. In this study, the irregular and seasonal components are both assumed to be linked to the rainfall triggering factor $\left(y_{t}=T_{t} D_{t}\right.$ with $\left.D_{t}=S_{t} I_{t}\right)$. The trend is determined by curve fitting of a fourth-order polynomial (parametric detrending). The result is a detrended unitless time series $\left(D_{t}\right)$ with both variance and mean trend removed. The time series decomposition process is illustrated with the A16 extensometer in Fig. 4.
Table 3. Calibration and performance of the five tested $\mathrm{ET}_{0}$ methods, in relation to the FAO-56 PM ET 0 standard (Penman-Monteith method defined in the FAO-56 paper). All the $\mathrm{ET}_{0}$ methods are detailed in Appendix A. $a, b$ and $R^{2}$ are the results of linear regression between FAO-56 PM ET 0 and tested $\mathrm{ET}_{0}$ methods. RMSE is the root mean square error.

\begin{tabular}{lllll}
\hline Method & $a$ & $b$ & $R^{2}$ & RMSE \\
\hline $\mathrm{HS} \mathrm{ET}_{0}$ & 0.920 & 0.130 & 0.917 & 0.548 \\
Turc ET & 0.880 & 0.434 & 0.900 & 0.588 \\
$\mathrm{PS} \mathrm{ET}_{0}$ & 0.352 & 0.365 & 0.919 & 0.533 \\
$\mathrm{M} \mathrm{ET}_{0}$ & 1.107 & -0.018 & 0.910 & 0.565 \\
$\mathrm{PM}_{\text {red }} \mathrm{ET}_{0}$ & 0.994 & 0.013 & 0.932 & 0.505 \\
\hline
\end{tabular}

\section{Results of the recharge estimation with the LRIW method}

\subsection{Calibration of $R_{S}$ and $E T_{0}$ methods}

The two calibrated $R_{\mathrm{S}}$ methods show good results with respect to $R_{\mathrm{S}}$ measured at the reference weather stations. The $\mathrm{BC}_{\text {mod }} R_{\mathrm{S}}$ method is selected as it shows a better performance $\left(R^{2}=0.864\right.$; RMSE $\left.=1.567\right)$ than the $\mathrm{HS}_{\text {mod }} R_{\mathrm{S}}$ method $\left(R^{2}=0.847\right.$; RMSE $\left.=1.625\right)$. Equation (4) presents the calibrated $\mathrm{BC} R_{\mathrm{S}}$ method with all the calibrated coefficients.

$\mathrm{BC}_{\mathrm{mod}} R_{\mathrm{S}}=0.669 R a\left[1-\exp \left(-0.010(\alpha \Delta T)^{2.053}\right)\right]+1.733$

The cloud cover adjustment factor $\alpha$ is either equal to 0.79 (cloud impact) or to 1 . All the equation terms are described in the Appendix $\mathrm{A}$. The $\mathrm{BC}_{\text {mod }} R_{\mathrm{S}}$ calibrated method is then used to compute $R_{\mathrm{S}}$ input data of the five $\mathrm{ET}_{0}$ reduced-set methods.

Overall, all of the $\mathrm{ET}_{0}$ methods tested show good results for regional calibration and are all suitable for the Séchilienne site (Table 3). Among the $\mathrm{ET}_{0}$ methods tested, the $\mathrm{PM}_{\text {red }} \mathrm{ET}_{0}$ method shows the best performance $\left(R^{2}=0.932\right.$; RMSE $=0.505$ ) and requires only a low regional adjustment ( $a=0.994$ and $b=0.013$ ). Therefore, the $\mathrm{PM}_{\mathrm{red}} \mathrm{ET}_{0}$ method is selected to compute $\mathrm{ET}_{0}$ for the Séchilienne site (hereafter referred to as $\left.\mathrm{ET}_{0 \mathrm{~S} e ́ c h}\right)$. Figure 5 displays the estimated $\mathrm{ET}_{0 \mathrm{~S} e ́ c h}$ versus the FAO-56 PM computation for each reference weather station.

Equation (5) is the final calibrated $\mathrm{PM}_{\mathrm{red}} \mathrm{ET}_{0}$ method with all the calibrated coefficients. The input $R_{\mathrm{n}}$ term is deduced from the calibrated $\mathrm{BC}_{\text {mod }} R_{\mathrm{S}}$ method (Eq. 4).

$$
\mathrm{ET}_{0} \text { Séch }=0.994 \frac{0.408 \Delta\left(R_{\mathrm{n}}-0\right)+\gamma \frac{900}{T_{\mathrm{avg}}+273} 1.5\left(e_{\mathrm{s}}-e_{\mathrm{a}}\right)}{\Delta+\gamma(1+0.341 .5)}+0.013
$$

\subsection{Recharge-area parameters}

Subareas are expressed in percentages of the whole recharge area (Table 4, Fig. 6). Two types of vegetation cover, pasture and forest, are defined using aerial photographs, with 

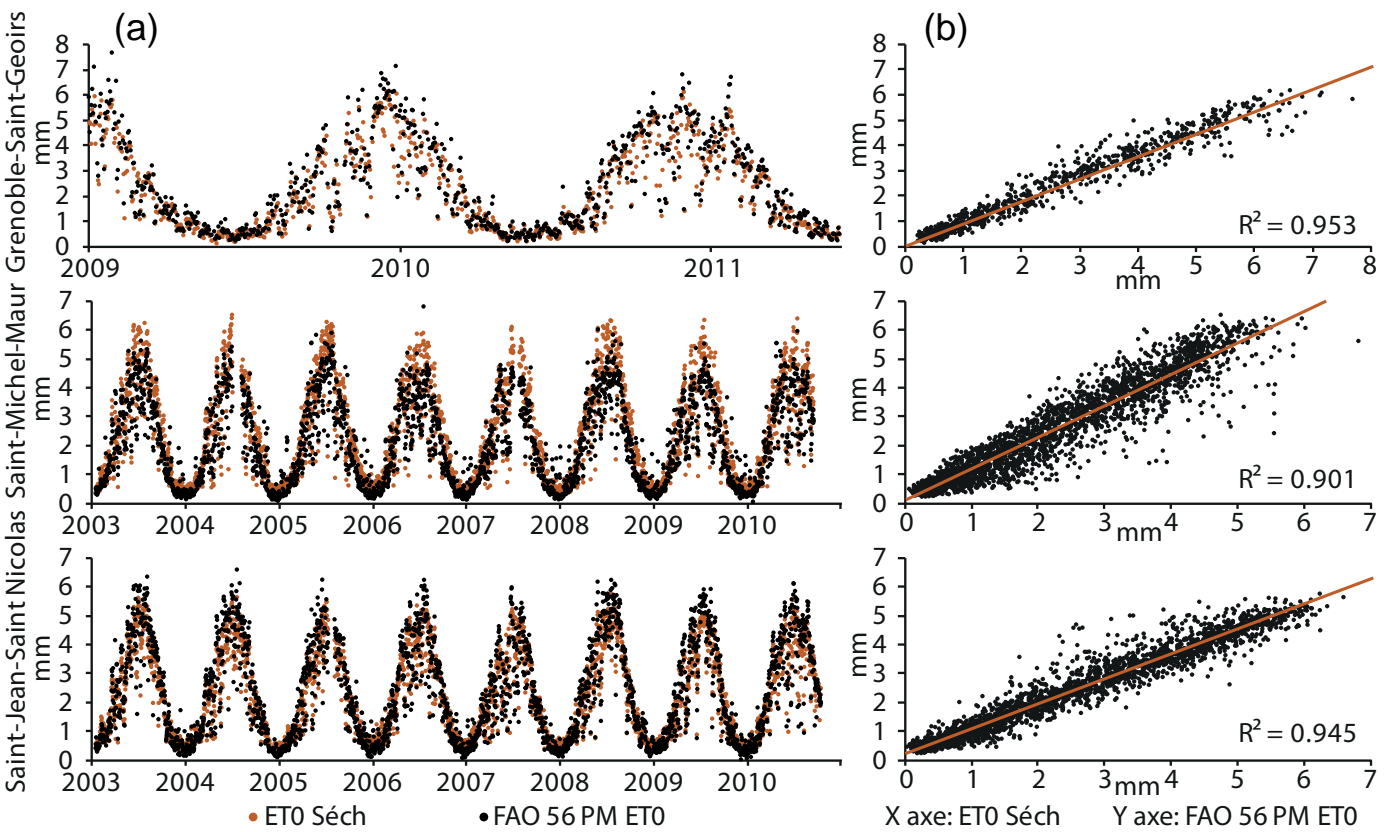

Figure 5. $\mathrm{ET}_{0}$ regional calibration results at the three reference weather stations (Grenoble-Saint-Geoirs, Saint-Jean-Saint-Nicolas and SaintMichel-Maur). (a) $\mathrm{ET}_{0 \mathrm{Séch}}$ and FAO-56 PM ET 0 as a function of time. (b) Linear regression between ET $0 \mathrm{Sé}$ ( $x$ axis) and FAO-56 PM ET 0 ( $y$ axis). $\mathrm{ET}_{0 \text { Séch }}$ stands for $\mathrm{ET}_{0}$ computed with the combination of calibrated $\mathrm{ET}_{0}$ Penman-Monteith reduced-set method and calibrated $R_{\mathrm{S}}$ modified Bristow-Campbell method.
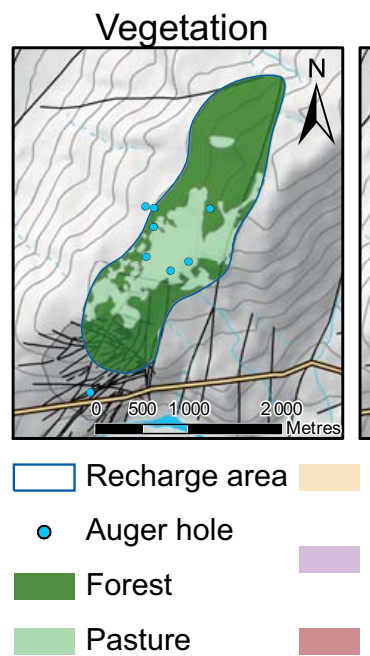

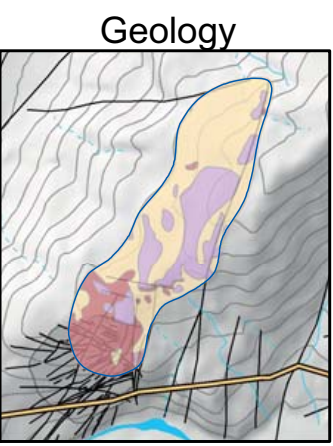

Superficial formation

Sedimentary cover

Micaschist bedrock
Slope gradient

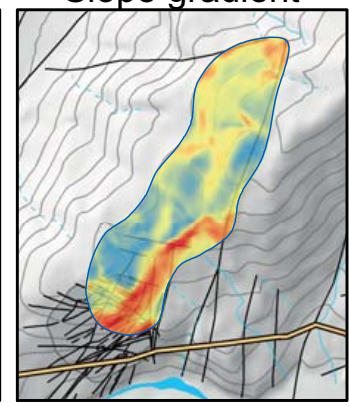

$50^{\circ}$

$0^{\circ}$ Slope gradient

Infiltration structure

Unstable slope



Stream/River

fault / fracture

Elevation contour (100 $\mathrm{m}$ above sea level)

Figure 6. Factor subareas, auger holes and infiltration structures used for the estimation of recharge-area parameters.

proportions of 23 and $53 \%$, respectively. The Séchilienne forest is mainly composed of beeches (Fagus sylvatica) and conifers (Picea excelsa), which are associated occasionally with ashes (Fraxinus) and sweet chestnuts (Castanea sativa). Three main geology subareas, mica schist bedrock (15\%), sedimentary cover (20\%) and superficial formations (41\%), are defined through examination of the geological map and field investigations. Infiltration structures are centred on the major faults identified on the geological map, on lineaments deduced from aerial-photograph analysis and on geomorphological features (sinkholes, cracks, etc.). A $50 \mathrm{~m}$ wide influence zone is added to the identified objects, leading to an infiltration-structure subarea representing $24 \%$ of the recharge area.

For $K_{\mathrm{c}}$ estimation, the proportion of beeches and conifers is assumed to be identical for the Séchilienne forest (each $50 \%$ of forest subarea) and other species are ignored. $K_{\mathrm{c}}$ values are set to 0.71 and 0.97 for conifers, and to 0.78 and 0.9 
Table 4. Estimation of $K_{\mathrm{c}}$, SAWC and runoff for the recharge area of the Séchilienne landslide. Geology and vegetation are the subarea factors identified and expressed in relative proportion of the recharge area. The average slope gradient is the slope gradient for each identified vegetation subarea factor. $K_{\mathrm{c}}, R_{\text {coeff }}$ and SAWC columns are the estimated values for each subarea factor. $K_{\mathrm{c}}$ RA, SAWC RA and $R_{\mathrm{coeff}}$ RA columns are the contribution of each subarea parameter at the scale of the recharge area. The recharge area (bottom row) stands for the estimation at the scale of the recharge area.

\begin{tabular}{|c|c|c|c|c|c|c|c|c|c|}
\hline Geology suba & $\mathrm{ea}(\%)$ & $\begin{array}{l}\text { Vegetation } \\
\text { subarea } \\
(\%)\end{array}$ & $\begin{array}{l}\text { Average } \\
\text { slope } \\
\text { gradient } \\
\left(^{\circ}\right)\end{array}$ & $\begin{array}{l}K_{\mathrm{c}} \\
\min . \\
\max .\end{array}$ & $\begin{array}{l}K_{\mathrm{c}} \mathrm{RA} \\
\min . \\
\max .\end{array}$ & $\begin{array}{l}R_{\text {coeff }} \\
(\%)\end{array}$ & $\begin{array}{l}R_{\text {coeff }} \\
\text { RA } \\
(\%)\end{array}$ & $\begin{array}{l}\text { SAWC } \\
(\mathrm{mm})\end{array}$ & $\begin{array}{l}\text { SAWC } \\
\text { RA } \\
(\mathrm{mm})\end{array}$ \\
\hline $\begin{array}{l}\text { Mica schist } \\
\text { Sedimentary } \\
\text { Superficial } \\
\text { formations }\end{array}$ & $\begin{array}{l}3 \\
9 \\
11\end{array}$ & $\begin{array}{l}\text { Pasture } \\
23\end{array}$ & 14.0 & $\begin{array}{l}0.85 \\
1\end{array}$ & $\begin{array}{l}0.256 \\
0.301\end{array}$ & 22 & 5.1 & $\begin{array}{l}173 \\
100 \\
112\end{array}$ & $\begin{array}{l}5 \\
9 \\
12\end{array}$ \\
\hline $\begin{array}{l}\text { Mica schist } \\
\text { Sedimentary } \\
\text { Superficial } \\
\text { formations }\end{array}$ & $\begin{array}{l}12 \\
11 \\
30\end{array}$ & $\begin{array}{l}\text { Forest } \\
53\end{array}$ & 20.6 & $\begin{array}{l}0.745 \\
0.935\end{array}$ & $\begin{array}{l}0.521 \\
0.654\end{array}$ & 15 & 7.7 & $\begin{array}{l}254 \\
81 \\
133\end{array}$ & $\begin{array}{l}30 \\
9 \\
41\end{array}$ \\
\hline $\begin{array}{l}\text { Outcrop } \\
\text { no soil } \\
\text { Recharge } \\
\text { area }\end{array}$ & 100 & $\begin{array}{l}24 \\
100\end{array}$ & - & - & $\begin{array}{l}- \\
0.777 \\
0.955\end{array}$ & 0 & $\begin{array}{l}0 \\
12.8\end{array}$ & - & $\begin{array}{l}0 \\
106\end{array}$ \\
\hline
\end{tabular}

for beeches according to Verstraeten et al. (2005). Most pastures are anthropogenic and consist of grass. $K_{\mathrm{c}}$ values are set to 0.85 and 1 according to Allen et al. (1998). Infiltration structure subareas are not taken into account in the $K_{\mathrm{c}}$ estimation, so the relative proportions of pasture and forest become 30 and $70 \%$, respectively. The contribution of each subarea (column $K_{\mathrm{c}} \mathrm{RA}$, Table 4) allows determining the recharge area $K_{\mathrm{c}}$ values at the scale of the recharge area (0.777 to 0.955$)$.

The combination of geology and vegetation subareas results in six types of SAWC subareas (Table 4). For each SAWC subarea, at least one auger hole was drilled. For each soil auger core, the soil texture, the stoniness and the organic-matter content are estimated by morphological description (Baize and Jabiol, 2011). Based on these estimations, the SAWC is then computed using the pedotransfer functions of Jamagne et al. (1977) and Bruand et al. (2004). The average estimation of SAWC at the recharge area scale is $106 \pm 10 \mathrm{~mm}$ (rounded to $105 \mathrm{~mm}$ ).

To estimate $R_{\text {coeff }}$, an average slope gradient is computed from slope gradient analysis of the DEM and is assigned to each vegetation subarea. Pasture and forest subareas show an average slope gradient of 14 and $20.6^{\circ}$, respectively. $R_{\text {coeff }}$ values of $22 \%$ for pasture and $15 \%$ for forest are deduced from the Sautier chart (Musy and Higy, 2011). This chart was developed for Switzerland where environmental conditions are similar to the French Alps. A $12.8 \%$ runoff coefficient is then estimated at the recharge area scale, according to the respective proportions of vegetation subareas (Table 4).

\subsection{Sensitivity analysis of the parameters of the recharge area}

Sensitivity analysis is performed for SAWC ranging from 0 (100\% of infiltration structures corresponding to precipitation) to $145 \mathrm{~mm}$ of SAWC (0\% infiltration structures $+10 \mathrm{~mm}$ of SAWC uncertainties measurement) with increments of $10 \mathrm{~mm}$. The coupled surface $R_{\text {coeff }}$ ranges from 0 to $16.3 \%$ (with increments of about $1 \%$ ). For each combination, recharge is computed according to the soil-water balance (step 3; Figs. 1, 2) with (i) the temperature estimated for the recharge area (Appendix B), (ii) the precipitation recorded at Mont Sec weather station, and (iii) the parameters of the recharge area.

All the best computations have a 1-day lag, with periods ranging from 56 to 104 days (Fig. 7a, Table 5). The best $R^{2}$ obtained from recharge is obtained with both the estimated recharge-area parameters $(\mathrm{SAWC}=105 \mathrm{~mm}$, $\left.R^{2}=0.618\right)$ and the recharge-area parameters for SAWC adjusted from $75\left(R^{2}=0.616\right)$ to $115 \mathrm{~mm}\left(R^{2}=0.617\right.$; Fig. 7b, Table 5). One of the best correlation performances is obtained for the estimated recharge-area parameters. This shows that the delimitation of the recharge area properly reflects the actual field conditions. The best correlation performance is assumed to be obtained with the estimated recharge-area parameters for $\mathrm{NH} 4$, i.e. testing $R^{2}$ obtained with the estimated recharge-area set $(\mathrm{SAWC}=105 \mathrm{~mm}) \mathrm{mi}-$ nus $R^{2}$ obtained with each of the other adjusted rechargeparameter sets of the sensitivity analysis (Table 5).

For all the recharge combinations tested, the LBCI values from bootstrap testing of $\mathrm{NH} 2$ are greater than 0 , allowing for 

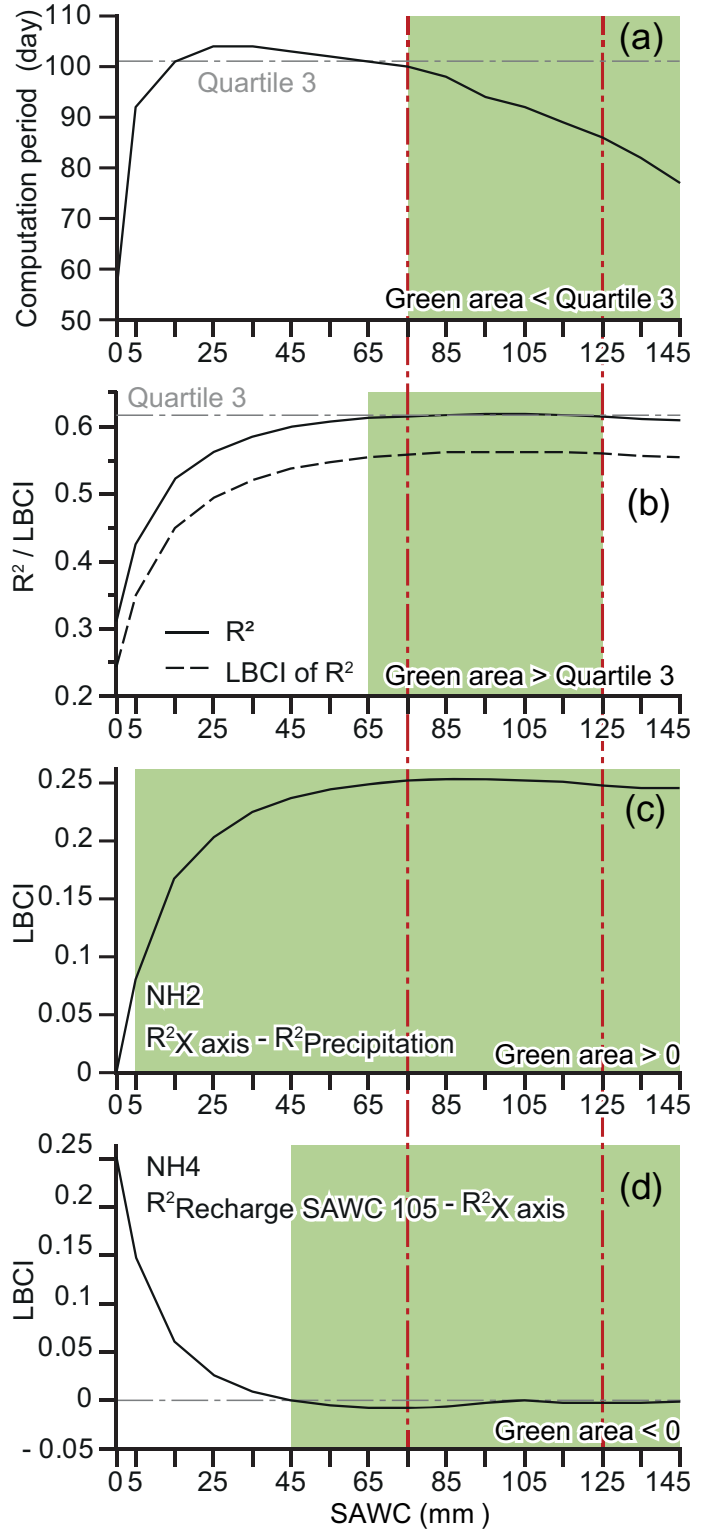

Figure 7. Results of the sensitivity analysis relative to SAWC for (a) the computation period, (b) the $R^{2}$ and the LBCI of $R^{2}$, (c) the LBCI of NH2 and (d) the LBCI of NH4.

the rejection of $\mathrm{NH} 2$ (Fig. 7c). In other words, it shows that the $R^{2}$ obtained with recharge is always significantly higher than the one computed with precipitation $\left(R^{2}=0.311\right)$ even for a SAWC of $5 \mathrm{~mm}\left(R^{2}=0.426\right.$; Table 5$)$. For the adjusted recharge-area parameter scenarios having SAWC values above $45 \mathrm{~mm}$, the LBCI values from bootstrap testing of $\mathrm{NH} 4$ are lower than 0 , not allowing for the rejection of NH4 (Table 5, Fig. 7d). In other words, it shows that the $R^{2}$ obtained with a SAWC of $105 \mathrm{~mm}$ is not significantly higher than the ones obtained from SAWC above $45 \mathrm{~mm}$. Rechargedisplacement correlations for SAWC values ranging from 75 (runoff $=9 \%$ ) to $115 \mathrm{~mm}$ (runoff $=13.9 \%$ ) show (i) a cumu- lative period computation $(n)$ below 101 days that is within the third quartile, (ii) an $R^{2}$ greater than 0.616 that is within the third quartile, (iii) LBCI values of $\mathrm{NH} 2$ greater than 0 , and (iv) LBCI values of NH4 lower than 0 (Table 5, Fig. 7). These SAWC and runoff values seem to statistically reflect the recharge area properties of the landslide and are suggested for further work on the Séchilienne landslide.

\subsection{Estimation of the recharge for the Séchilienne landslide}

For the remaining part of this paper, $R_{\mathrm{LRIW}}$ is based on the estimated recharge-area parameters (infiltration structures $=24 \%$, SAWC $=105 \mathrm{~mm}$, and $R_{\text {coeff }}=12.8 \%$ ). Indeed, among all solutions giving satisfying performances in the sensitivity analysis, these parameters arise from actual field data. $R_{\text {LRIW }}$ is compared with the precipitation signal in Fig. 8.

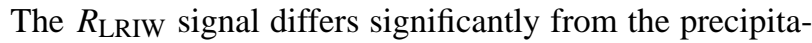
tion signals, marked by a high seasonal contrast. This is especially true during summer when $\mathrm{ET}_{\mathrm{c}}$ is important. Indeed, the first rainfall events after a dry period do not reach the aquifer until the SAWC is exceeded. Figure 9 shows the best correlation results for precipitation and $R_{\mathrm{LRIW}}$, together with A16 detrended daily displacements. The cumulative recharge signal reproduces well the displacement acceleration and deceleration phases, and especially the dry summers where displacement dramatically dropped (summers 1997, 1998, 2003, 2004 and 2009; Fig. 9b). On the contrary, the cumulative precipitation signal is more contrasted and more noisy, and does not manage to reproduce several peaks (in width as well as in intensity) of the detrended displacement signal (winters 1997, 2000, 2004, 2005 and 2010). In addition, the cumulative precipitation signal shows a weak correlation with displacement deceleration phases (summers 1998, 1999, 2000 2006, 2009 and 2010).

\section{Discussion}

\subsection{Relevance of the LRIW method}

Figure 10 summarises the comparison of the performances between the precipitation, the $R_{\mathrm{PMNE}}$ and the $R_{\mathrm{LRIW}}$ based on the NH1, NH2 and $\mathrm{NH} 3$ tests for the four displacement stations. LBCI values from bootstrap testing of $\mathrm{NH} 1$ are lower than 0 for 1101, A13 and A16 stations and greater than 0 for the G5 station. NH1 cannot be rejected, meaning that the $R^{2}$ values obtained with $R_{\text {PMNE }}$ are not significantly higher than those computed with precipitation, except for the G5 station. All LBCI values from bootstrap testing of $\mathrm{NH} 2$ and $\mathrm{NH} 3$ are greater than 0 , allowing for the rejection of these two null hypotheses for the four stations (Fig. 10a). Rejection of NH2 shows that the $R^{2}$ values obtained with $R_{\text {LRIW }}$ are significantly higher than those computed with precipitation. Similarly, rejection of NH3 shows that $R^{2}$ values 
Table 5. Sensitivity analysis results of the best correlation between precipitation/ $R_{\mathrm{LRIW}}$ and A16 extensometer detrended displacement. IS is for infiltration structures. SAWC is the soil available water capacity. LBCI is the lower bound of the confidence interval. $R^{2}$ row is the $R^{2}$ computed from recharge-area parameters indicated in each table row. Cumulative period $(n)$, shift factor $(\beta)$ and weighting factor $(\alpha)$ are the terms of Eq. (3). NH2 test: $R_{\text {row }}^{2}-R_{\text {precipitation. }}^{2}$ NH4 test: $R_{\mathrm{SAWC} 105}^{2}-R_{\text {row }}^{2}$.

\begin{tabular}{llllllllll}
\hline $\begin{array}{l}\text { SAWC } \\
\mathrm{mm}\end{array}$ & $\begin{array}{l}R_{\text {coeff }} \\
\%\end{array}$ & $\begin{array}{l}\text { IS } \\
\%\end{array}$ & $\begin{array}{l}\text { Cumulative } \\
\text { period }(n) \\
\text { day }\end{array}$ & $\begin{array}{l}\text { Shift } \\
\text { factor } \\
(\beta) \\
\text { day }\end{array}$ & $\begin{array}{l}\text { Weighting } \\
\text { factor } \\
(\alpha)\end{array}$ & $R^{2}$ & $\begin{array}{l}\text { LBCI } \\
\text { of } R^{2}\end{array}$ & $\begin{array}{l}\text { LBCI } \\
\text { of NH2 }\end{array}$ & $\begin{array}{l}\text { LBCI } \\
\text { of NH4 }\end{array}$ \\
\hline 0 & & & 1 & 0.1697 & 0.311 & 0.243 & 0 & \\
5 & 0.0 & 100 & 56 & 1 & 0.1362 & 0.426 & 0.350 & 0.080 & 0.148 \\
15 & 0.6 & 96 & 92 & 1 & 0.1226 & 0.522 & 0.450 & 0.167 & 0.061 \\
25 & 1.8 & 89 & 101 & 1 & 0.1259 & 0.563 & 0.494 & 0.203 & 0.027 \\
35 & 4.0 & 82 & 104 & 1 & 0.1317 & 0.585 & 0.521 & 0.224 & 0.009 \\
45 & 5.4 & 68 & 103 & 1 & 0.1374 & 0.599 & 0.538 & 0.236 & 0.000 \\
55 & 6.6 & 61 & 102 & 1 & 0.143 & 0.608 & 0.548 & 0.244 & -0.005 \\
65 & 7.8 & 53 & 101 & 1 & 0.1484 & 0.613 & 0.555 & 0.249 & -0.007 \\
75 & 9.0 & 46 & 100 & 1 & 0.155 & 0.616 & 0.559 & 0.251 & -0.007 \\
85 & 10.3 & 39 & 98 & 1 & 0.1609 & 0.618 & 0.562 & 0.253 & -0.006 \\
95 & 11.5 & 32 & 94 & 1 & 0.1648 & 0.618 & 0.563 & 0.253 & -0.003 \\
105 & 12.8 & 24 & 92 & 1 & 0.1689 & 0.618 & 0.563 & 0.252 & 0 \\
115 & 13.9 & 18 & 89 & 1 & 0.1727 & 0.617 & 0.562 & 0.251 & -0.002 \\
125 & 15.1 & 10 & 86 & 1 & 0.1745 & 0.614 & 0.560 & 0.248 & -0.002 \\
135 & 16.3 & 3 & 82 & 1 & 0.1746 & 0.611 & 0.556 & 0.245 & -0.002 \\
145 & 16.3 & - & 77 & 1 & 0.1731 & 0.609 & 0.555 & 0.245 & -0.002 \\
\hline & & & & & & & & & \\
\hline
\end{tabular}

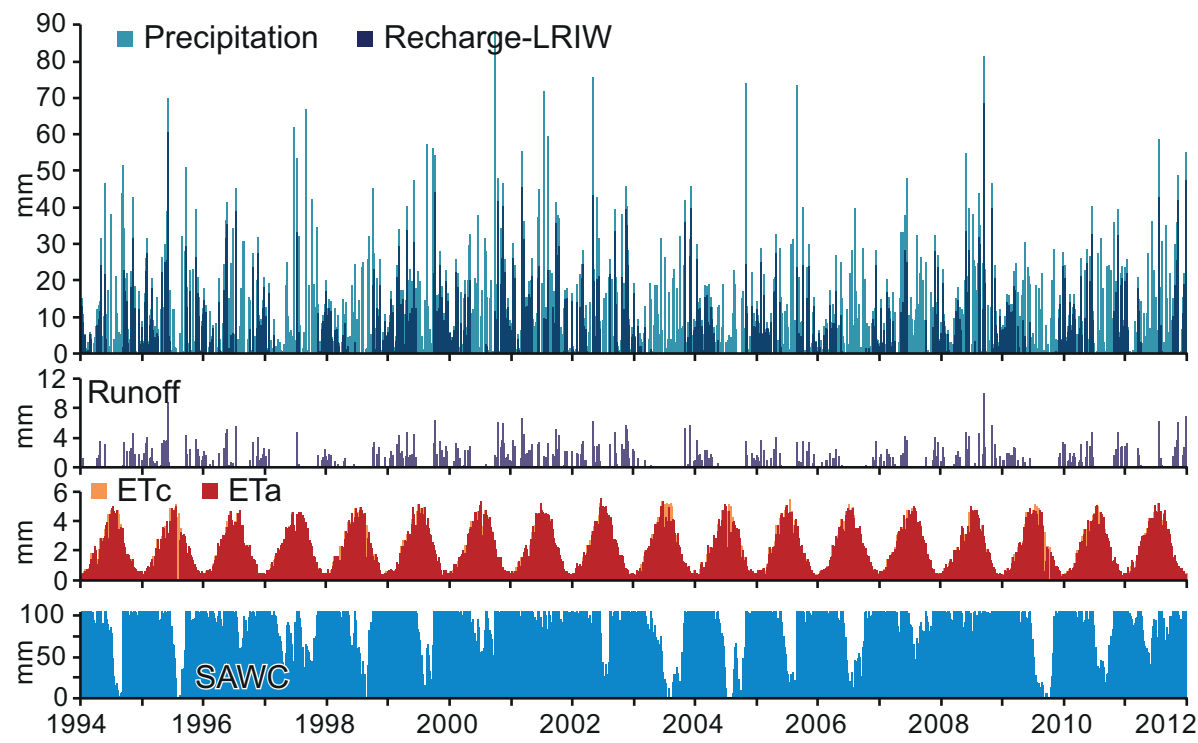

Figure 8. Recharge computation with the LRIW method at Séchilienne with an SAWC of $105 \mathrm{~mm}$ and a runoff coefficient of $12.8 \%$. ET : $_{\text {. }}$ specific vegetation evapotranspiration; ET $_{\mathrm{a}}$ : actual vegetation evapotranspiration, SAWC: soil available water capacity.

obtained with $R_{\text {LRIW }}$ are significantly higher than those computed with $R_{\text {PMNE }} \cdot R^{2}$ values vary from 0.0006 to 0.343 for precipitation, from 0.076 to 0.444 for $R_{\mathrm{PMNE}}$ and from 0.243 to 0.586 for $R_{\mathrm{LRIW}}$, for G5 and A16 extensometer, respectively (Table 2 ). On average, $R_{\text {PMNE }}$ allows increasing the $R^{2}$ value by $29 \%$ relative to precipitation, while $R_{\text {LRIW }}$ allows increasing the $R^{2}$ by $78 \%$ (Fig. 10b). The $R^{2}$ values obtained with $R_{\text {LRIW }}$ are $38 \%$ higher on average than those obtained with $R_{\mathrm{PMNE}}$

These results are confirmed by the LBCI and by the observed values of the $\mathrm{NH} 2$ test which are always greater than those from the NH1 test as well as by the positive LBCI values of the NH3 test (Fig. 10). The correlation performance for the recharge estimated with the LRIW method signif- 

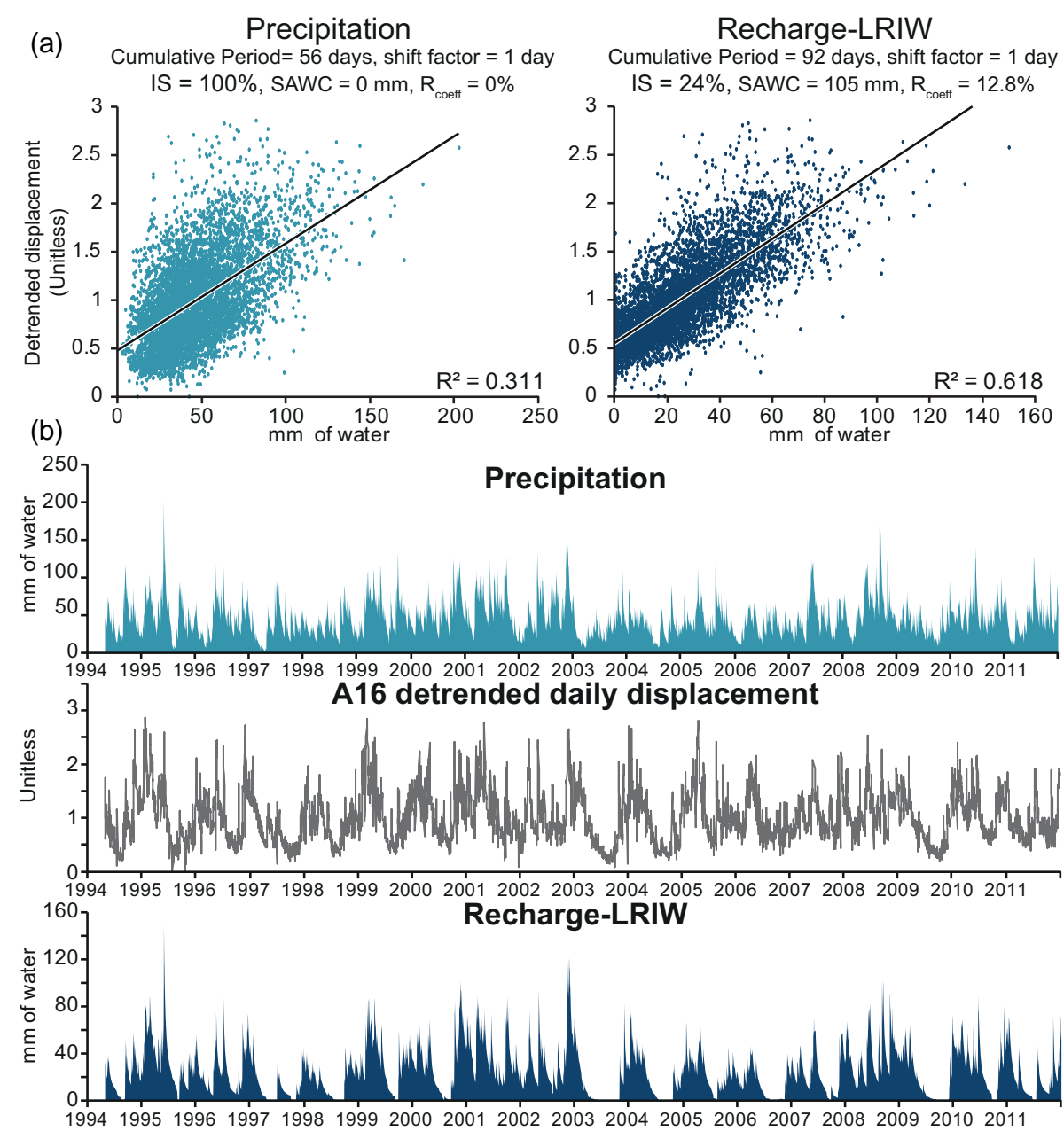

Figure 9. Best linear correlations for precipitation and recharge computed with the LRIW method. IS is for infiltration structures. SAWC is soil available water capacity. Cumulative period $(n)$ and shift factor $(\beta)$ are the terms of Eq. (3). (a) Linear regression between precipitation/ $R_{\text {LRIW }}$ and A16 detrended displacement. (b) Correlation between precipitation/ $R_{\text {LRIW }}$ and A16 detrended displacement as a function of time.

icantly exceeds the performance of the two other signals, making the LRIW method particularly appropriate to be used in landslide studies. A discussion about the benefit of this study for the understanding of the rainfall-displacement relationship in the case of the Séchilienne landslide can be found in Appendix C.

\subsection{Applicability of the LRIW method to other landslides}

Several studies have shown the relevance of the recharge signal for various landslide types: coastal landslides (Maquaire, 2000; Bogaard et al., 2013), unstable embankment slope landslides (Cartier and Pouget, 1987; Delmas et al., 1987; Matichard and Pouget, 1988) and deep-seated earth flow landslides (Malet et al., 2003; Godt et al., 2006). In addition, destabilisation of shallow landslides is known to be influenced by antecedent soil moisture and precipitation
(Brocca et al., 2012; Garel et al., 2012; Ponziani et al., 2012). Recharge, which implicitly combines antecedent soil moisture and precipitation, can be a significant parameter to consider.

Although the method proposed in this study has not yet been tested at other sites, there are several arguments which suggest its applicability elsewhere. First, the FAO PenmanMonteith method used in this study is considered worldwide as the evapotranspiration method standard (Allen et al., 1998; Shahidian et al., 2012). Several evapotranspiration methods were developed locally and many of them can be calibrated against reference methods in other contexts (Hargreaves and Allen, 2003; Yoder et al., 2005; Alkaeed et al., 2006; Igbadun et al., 2006; Trajkovic, 2007; Alexandris et al., 2008; LópezMoreno et al., 2009; Sivaprakasam et al., 2011; Tabari and Talaee, 2011; Shahidian et al., 2012; Tabari et al., 2013). Otherwise, the Penman-Monteith or Hargreaves-Samani methods are recommended (Allen et al., 1998). Several solar radi- 
(a)


Figure 10. Performance of the LRIW workflow. (a) Bootstrap distribution of NH1, NH2 and NH3 tests for four displacement recording stations. (b) $R^{2}$ values for the four displacement recording stations obtained with the precipitation, recharge PMNE, and recharge LRIW. LBCI is the lower bound of the confidence interval. G5 station is disregarded in the the performance average variation calculation since the $R^{2}$ value obtained at G5 from precipitation is close to 0 , therefore leading to a non-representative variation.

ation methods were developed and can be applied worldwide if locally calibrated, allowing for the estimation of evapotranspiration from temperature alone (Allen et al., 1998; Almorox, 2011). Recharge-area parameters can be estimated locally or with local or global literature reference values. The use of global values will increase recharge estimation uncertainties. However, the implementation of a sensitivity analysis allows refining the recharge-area parameters in order to compensate for the lack of site-specific data. Pachepsky and Rawls (2004) developed pedotransfer functions to estimate SAWC for various regions of the world. $R_{\text {coeff }}$ values from the widely used rational method can be applied, as well as most of the runoff coefficients from the literature (McCuen, 2005; Musy and Higy, 2011). In addition, pedotransfer functions can also be used for runoff estimation. Lastly, vegetation coefficients are available from local surveys (Gochis and 
Cuenca, 2000; Verstraeten et al., 2005; Hou et al., 2010), but can also be found in the literature for many species (Allen et al., 1998).

\section{Conclusion and perspectives}

A method based on a soil-water balance, named LRIW, is developed to compute recharge on a daily interval, requiring the characterisation of evapotranspiration and parameters characterising the recharge area (soil available water capacity and runoff). A workflow is developed to compute daily groundwater recharge and requires the records of precipitation, air temperature, relative humidity, solar radiation and wind speed within or close to the landslide. The determination of the parameters of the recharge area is based on a spatial analysis requiring field observations and spatial data sets (digital elevation models, aerial photographs and geological maps). Once determined, the parameters are refined with a sensitivity analysis.

The method has been tested on the Séchilienne landslide. The tests demonstrate that the performance of the correlation with landslide displacement velocity data is significantly enhanced using the LRIW estimated recharge. The $R^{2}$ values obtained with the LRIW recharge are $78 \%$ higher on average than those obtained with precipitation and are $38 \%$ higher on average than those obtained with recharge computed with a commonly used simplification in several landslide studies (recharge $=$ precipitation minus non-calibrated $\mathrm{ET}_{0}$ ). The sensitivity analysis of the LRIW workflow appears to be an appropriate alternative to estimate or to refine soilwater balance parameters of the recharge area, especially in the case of insufficient field investigations or in the absence of the necessary spatial data set.
The LRIW workflow is developed to be as universal as possible in order to be applied to other landslides. The workflow is developed in order to be sufficiently simple to guide any non-hydrogeology specialist who intends to estimate the recharge signal in the case of rainfall-landslide displacement studies. Within this scope, a software is planned to be developed in the near future in order to provide a user-friendly tool for recharge estimation. In addition, the LRIW workflow also enables the reconstruction of retrospective time series for sites recently equipped with weather stations designed to measure a full set of parameters. A further step will have to account for the spatial and temporal variabilities of precipitation and recharge area properties, thus providing a better estimation of the recharge. In addition, taking recharge into account can assist in determining a warning rainfall threshold for the deep-seated slope movements. 
Appendix A: Equations for evapotranspiration and solar radiation methods

\section{A1 Equation parameter terms for all equations}

$\begin{array}{ll}R_{\mathrm{a}} & \text { extraterrestrial solar radiation }\left(\mathrm{MJ} \mathrm{m}^{-2} \mathrm{day}^{-1}\right) \\ R_{\mathrm{S}} & \text { solar radiation }\left(\mathrm{MJ} \mathrm{m}^{-2} \mathrm{day}^{-1}\right) \\ R_{\mathrm{n}} & \text { net solar radiation }\left(\mathrm{MJ} \mathrm{m}^{-2} \mathrm{day}^{-1}\right) \\ N & \text { maximum possible duration of sunshine }(\mathrm{h}) \\ n & \text { actual daily duration of sunshine }(\mathrm{h}) \\ T_{\mathrm{avg}} & \text { average air temperature at } 2 \mathrm{~m} \text { height }\left({ }^{\circ} \mathrm{C}\right) \\ T_{\mathrm{min}} & \text { minimum air temperature at } 2 \mathrm{~m} \text { height }\left({ }^{\circ} \mathrm{C}\right) \\ T_{\mathrm{max}} & \text { maximum air temperature at } 2 \mathrm{~m} \mathrm{height}\left({ }^{\circ} \mathrm{C}\right) \\ G & \text { soil heat flux density }\left(\mathrm{MJ} \mathrm{m}^{-2} \mathrm{day}^{-1}\right) \\ \gamma & \text { psychometric constant }\left(\mathrm{kPa}^{\circ} \mathrm{C}^{-1}\right) \\ u_{2} & \text { wind speed at } 2 \mathrm{~m} \text { height }\left(\mathrm{m} \mathrm{s}^{-1}\right) \\ e_{\mathrm{S}} & \text { mean saturation vapour pressure }(\mathrm{kPa}) \\ e_{\mathrm{a}} & \text { actual vapour pressure }(\mathrm{kPa}) \\ e^{\mathrm{O}} & \text { saturation vapour pressure at the air temperature } T \\ & \text { (kPa) } \\ \Delta & \text { slope of vapour pressure curve }\left(\mathrm{kPa}{ }^{\circ} \mathrm{C}^{-1}\right] \\ \mathrm{RH} & \text { relative humidity }(\%) \\ \alpha & \text { cloud cover adjustment factor }(\text { unitless })\end{array}$

The procedure for calculating these equation terms are given in the FAO-56 guidelines for computing crop water requirements (Allen et al., 1998).

\section{A2 Solar radiation $\left(\boldsymbol{R}_{\mathrm{S}}\right)$}

The solar radiation $\mathrm{BC} R_{\mathrm{S}}$ is obtained from the BristowCampbell method (Bristow and Campbell, 1984):

$$
\begin{aligned}
\mathrm{BC} R_{\mathrm{S}}= & A_{\mathrm{BC}} R a\left[1-\exp \left(-B_{\mathrm{BC}}\left(\alpha \Delta T_{\mathrm{BC}}\right)^{C_{\mathrm{BC}}}\right)\right] \\
& \text { with } \Delta T_{\mathrm{BC}}=T_{\max (j)}-\frac{T_{\min (j)}+T_{\min (j+1)}}{2} .
\end{aligned}
$$

The solar radiation HS $R_{\mathrm{S}}$ obtained from the HargreavesSamani method (Hargreaves and Samani, 1985):

$$
\begin{aligned}
& \mathrm{HS} R_{\mathrm{S}}=A_{\mathrm{HS}} R a\left(\Delta T_{\mathrm{HS}}\right)^{B_{\mathrm{HS}}} \\
& \quad \text { with } \Delta T_{\mathrm{HS}}=T_{\max (j)}-T_{\min (j)},
\end{aligned}
$$

where $j$ is for the current target day and $j+1$ is for the following day; $A_{\mathrm{BC}}, B_{\mathrm{BC}}$, and $C_{\mathrm{BC}}$ are the BristowCampbell empirical coefficients (no default values) and $A_{\mathrm{HS}}$ and $B_{\mathrm{HS}}$ are the Hargreaves-Samani empirical coefficients $\left(A_{\mathrm{HS}}=0.16\right.$ and $\left.B_{\mathrm{HS}}=0.5\right)$.

In this study, the modified forms of the $R_{\mathrm{S}}$ equations of Bristow-Campbell and Hargreaves-Samani are implemented: (i) a constant is added to take into account the possibility of a $R_{\mathrm{S}}$ estimation shift, (ii) the $\Delta T$ from the BristowCampbell method is used in both equations, and (iii) a cloud cover adjustment factor $\alpha$ is applied to $\Delta T$ since, for cloudy conditions, $\Delta T$ can produce an estimate larger than the incoming solar radiation (Bristow and Campbell, 1984).

Bristow-Campbell modified equation $\left(\mathrm{BC}_{\text {mod }} R_{\mathrm{S}}\right)$ :

$$
\mathrm{BC}_{\mathrm{mod}} R_{\mathrm{S}}=A_{\mathrm{BC}} R a\left[1-\exp \left(-B_{\mathrm{BC}}(\alpha \Delta T)^{C_{\mathrm{BC}}}\right)\right]+D_{\mathrm{BC}} .
$$

Hargreaves-Samani modified equation $\left(\mathrm{HS}_{\text {mod }} R_{\mathrm{S}}\right)$ :

$$
\mathrm{HS}_{\mathrm{mod}} R_{\mathrm{S}}=A_{\mathrm{HS}} R a(\alpha \Delta T)^{B_{\mathrm{HS}}}+C_{\mathrm{HS}}
$$

with $\Delta T=T_{\max (j)}-\frac{T_{\min (j)}+T_{\min (j+1)}}{2}$, where $j$ is for the current day and $j+1$ is for the following day; $A_{\mathrm{BC}}, B_{\mathrm{BC}}, C_{\mathrm{BC}}$, and $D_{\mathrm{BC}}$ are the Bristow-Campbell regional calibration coefficients and $A_{\mathrm{HS}}, B_{\mathrm{HS}}$, and $C_{\mathrm{HS}}$ are the Hargreaves-Samani regional calibration coefficients.

The $\alpha$ coefficient is applied for the two first rain-event days since, for a rain period longer than two days, the value of the $R_{\mathrm{S}}$ estimated from $\Delta T$ and the actual $R_{\mathrm{S}}$ value become almost identical. If $\Delta T$ on the day before a rain event $\left(\Delta T_{j-1}\right)$ is less than $\Delta T_{j-2}$ by more than $2{ }^{\circ} \mathrm{C}$, the coefficient $\alpha$ is also applied assuming that cloud cover was already significantly present. For the remaining days, $\alpha$ is not applied $(\alpha=1)$. A $2{ }^{\circ} \mathrm{C}$ threshold and a 2 day period are used (Bristow and Campbell, 1984). In this study, the calibration of $\alpha$ is based on the principle that if this adjustment is not relevant, a calibrated $\alpha$ coefficient would be equal to 1 (no effect).

$R_{\mathrm{S}}$ can also be calculated with the Angström formula using sunshine duration data recorded at a weather station (FAO-56 guidelines, Allen et al., 1998):

$R_{\mathrm{S}}=\left(a_{\mathrm{S}}+b_{\mathrm{s}} \frac{n}{N}\right) R_{\mathrm{a}}$

where: $a_{\mathrm{s}}+b_{\mathrm{s}}$ is the fraction of extraterrestrial solar radiation reaching the Earth surface on clear days (default values, $a_{\mathrm{s}}=0.25$ and $b_{\mathrm{s}}=0.5$ ).

\section{A3 Reference vegetation evapotranspiration $\left(\mathbf{E T}_{\mathbf{0}}\right)$}

The reference vegetation evapotranspiration FAO-56 PM $\mathrm{ET}_{0}$ obtained from the Penman-Monteith method modified form from the FAO paper number 56 (Allen et al., 1998) is

FAO-56 PM ET $0=\frac{0.408 \Delta\left(R_{\mathrm{n}}-G\right)+\gamma \frac{900}{T_{\mathrm{avg}}+273} u_{2}\left(e_{\mathrm{s}}-e_{\mathrm{a}}\right)}{\Delta+\gamma\left(1+0.34 u_{2}\right)}$.

The reference vegetation evapotranspiration $\mathrm{HSET}_{0}$ obtained from the Hargreaves-Samani method (Hargreaves and Samani, 1985) is

$\mathrm{HS} \mathrm{ET}_{0}=0.01350 .408 R_{\mathrm{S}}\left(T_{\mathrm{avg}}+17.8\right)$.

The 0.408 unit conversion factor is added to the original formula in order to compute $\mathrm{ET}_{0}$ in millimetres per day with $R_{\mathrm{S}}$ in megajoules per square metre per day. 
The reference vegetation evapotranspiration Turc $\mathrm{ET}_{0}$ obtained from the Turc method (Turc, 1961) is

$$
\begin{aligned}
& \text { for } \mathrm{RH}>50 \% \text {, Turc } \mathrm{ET}_{0} \\
& =0.01333 \frac{T_{\mathrm{avg}}}{T_{\mathrm{avg}}+15}\left(23.9001 R_{\mathrm{S}}+50\right),
\end{aligned}
$$

for $\mathrm{RH}<50 \%$, Turc $\mathrm{ET}_{0}$

$$
\begin{aligned}
& =0.01333 \frac{T_{\mathrm{avg}}}{T_{\mathrm{avg}}+15}\left(23.9001 R_{\mathrm{S}}+50\right) \\
& \left(1+\frac{50-\mathrm{RH}}{70}\right) .
\end{aligned}
$$

For the Séchilienne landslide, Eq. (A8) is preferred to Eq. (A9) because of an average greater than $50 \%$ relative humidity $(\mathrm{RH})$ of the nearby mountain weather stations (Chamrousse, $70 \%$; Saint-Michel-Maur, 66\%; Saint-Jean-SaintNicolas, $66 \%$ ).

The reference vegetation evapotranspiration $\mathrm{PTET}_{0}$ obtained from the Priestley-Taylor method (Priestley and Taylor, 1972) is

$\mathrm{PT} \mathrm{ET}_{0}=1.26 \frac{\Delta}{\Delta+\gamma}\left(R_{\mathrm{n}}-G\right)$.

The reference vegetation evapotranspiration $\mathrm{MET}_{0}$ obtained from the Makkink method (Makkink, 1957) is

$\mathrm{MET}_{0}=0.61 \frac{\Delta}{(\Delta+\gamma)} \frac{R_{\mathrm{S}}}{2.45}-0.012$.

The Penman-Monteith reduced-set method which allows calculating the reference vegetation evapotranspiration $\mathrm{PM}_{\text {red }} \mathrm{ET}_{0}$ is identical to the PM FAO-56 method (Eq. A6), but humidity and wind speed are estimated according to FAO-56 guidelines (Allen et al., 1998). The actual vapour pressure is estimated with Eq. (A12):

$e_{\mathrm{a}}=e^{0}\left(T_{\min }\right)=0.611 \exp \left(\frac{17.27 T_{\min }}{T_{\min }+237.3}\right)$.

In the case of the Séchilienne landslide, the wind speed is fixed at $1.5 \mathrm{~m} \mathrm{~s}^{-1}$ at a $2 \mathrm{~m}$ height $\left(2 \mathrm{~m} \mathrm{~s}^{-1}\right.$ by default), which is the daily average of the nearby mountain weather stations (Chamrousse, $2.33 \mathrm{~m} \mathrm{~s}^{-1}$; Saint-Michel-Maur, $0.95 \mathrm{~m} \mathrm{~s}^{-1}$; Saint-Jean-Saint-Nicolas, $1.26 \mathrm{~m} \mathrm{~s}^{-1}$ ).

\section{A4 Practical information}

The $\mathrm{ET}_{0}$ methods used in this study were developed for irrigation scheduling, for which the scope of application involves positive temperatures (plant water supply during the spring-summer growing period). However, in mountainous sites, winter temperatures are often below $0{ }^{\circ} \mathrm{C}$, and $\mathrm{ET}_{0} \mathrm{em}-$ pirical methods can compute negative $\mathrm{ET}_{0}$ values. Negative
$\mathrm{ET}_{0}$-computed values do not have any physical meaning and are therefore set to 0 for this study.

The Priestley-Taylor and Penman-Monteith $\mathrm{ET}_{0}$ methods use net solar radiation $\left(R_{\mathrm{n}}\right)$ instead of $R_{\mathrm{S}}$, which can be deduced from $R_{\mathrm{S}}$ following the FAO-56 guideline (Allen et al., 1998).

$\mathrm{ET}_{0}$ reduce-set methods do not take into account the wind speed variations. By removing saturated air from the boundary layer, wind increases evapotranspiration (Shahidian et al., 2012). Several studies show the influence of the wind speed on $\mathrm{ET}_{0}$ method performance and therefore on calibration (Itenfisu et al., 2003; Trajkovic, 2005; Trajkovic and Stojnic, 2007). For this study, the days with average wind speed above the 95th percentile of the data set (extreme values) are disregarded in the calibration.

\section{Appendix B: Temperature estimation at the Mont Sec weather station}

\section{B1 Method}

The temperatures at the Mont Sec weather station are estimated with the characterisation of the local air temperature gradient using two surrounding weather stations recording the temperatures at a daily rate (Luitel et La Mure weather stations). Once the local air temperature gradient is characterised, one of the stations is used to estimate the Mont Sec temperatures.

The decrease in air density with elevation leads to a decrease in air temperature known as the lapse rate ( $\mathrm{Ja}$ cobson, 2005). A commonly used value of this rate is $-6.5^{\circ} \mathrm{C} 1000 \mathrm{~m}^{-1}$. The air temperature can thus be related to elevation. In order to compute a local air temperature gradient, two weather stations surrounding the Séchilienne site are used: Luitel and La Mure (Table 1, Fig. 3). The Luitel station is located on the Séchilienne massif whereas the $\mathrm{La}$ Mure station is located about $18 \mathrm{~km}$ from the landslide. Both stations have weather conditions similar to the Séchilienne recharge area. Although the temperature estimation from the Luitel station would probably be more accurate, in order to maximise common interval lengths of temperatures with displacement records from 1994 to 2012, the La Mure station with records from 1992 to 2012 is preferred to estimate temperatures at Mont Sec.

The local air temperature gradient in relation to elevation is defined by Eq. (B1). The La Mure station minimum and maximum temperatures are used to estimate the temperatures at Luitel in relation to elevation, over their common recording period. A linear regression between temperatures measured at La Mure and Luitel is performed to determine the $a$ and $b$ coefficients. The $b$ coefficient, which combines the lapse rate $(\lambda)$ and the elevation difference, is then divided by the elevation difference of the two stations used for the calibration. 


$$
\begin{aligned}
& T_{(\text {Station })}=a T_{(\text {Mure })}+b=a T_{(\text {Mure })}+\lambda \text { Diff }_{\text {elevation }} \\
& \text { with } \text { Diff }_{\text {elevation }}=\text { Elevation }_{\text {Mure }}-\text { Elevation }_{\text {Station }} \text {, }
\end{aligned}
$$

where $a$ and $b$ are regional calibration coefficients; $T$ is the temperature minimum or maximum $\left({ }^{\circ} \mathrm{C}\right) ; \lambda$ is the tempera-

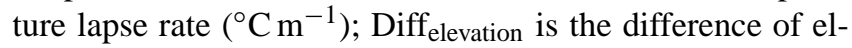
evation between two weather stations (m); elevation refers to the weather station elevation (ma.s.l.) and station to the target station (Luitel for calibration, Mont Sec for computation).

\section{B2 Results}

The recording period used for temperature calibration is from 6 July 2006 to 23 July 2012 (2193 records). This is a common data interval for the two weather stations used (La Mure and Luitel). The estimation of the local air temperature gradient shows a very good performance with $R^{2}$ equal to 0.895 $(\mathrm{LBCI}=0.839)$ and $0.916(\mathrm{LBCI}=0.862)$, and RMSE equal to 2.12 and 2.48 , respectively, for minimum and maximum daily temperature calibrations. Equations (B2) and (B3) are used to estimate temperatures at Mont $\mathrm{Sec}$ with temperatures measured at La Mure. Rather than taking the elevation of the Mont Sec weather station $(1147 \mathrm{~m})$, the average elevation of recharge area $(1200 \mathrm{~m})$ is used, resulting in a difference of elevation with La Mure of $319 \mathrm{~m}$. The estimated local air temperature gradient is $0.7^{\circ} \mathrm{C}$ per $100 \mathrm{~m}$ of elevation; the average of the $\lambda$ of the two following equations:

$$
\begin{aligned}
& T_{\min (\text { Mont Sec })}=0.911 T_{\min (\text { Mure })}-0.0056 \times 319 \\
& T_{\max (\text { Mont Sec })}=0.928 T_{\max (\text { Mure })}-0.0087 \times 319
\end{aligned}
$$

\section{Appendix C: Rainfall-displacement relationship in the case of the Séchilienne landslide}

The rainfall-displacement relationship is hereafter discussed for the precipitation and the $R_{\text {LRIW }}$ signals. Although the $R^{2}$ values are significantly variable from one station to another, the 5th and 95th percentiles and the observed value of the $\mathrm{NH} 2$ test are rather constant for the four displacement stations (respectively about $0.116,0.351$ and 0.235 ; Fig. 10a). These results show that the improvement of the correlation performance by using recharge rather than precipitation has the same order of magnitude for the four stations, whereas $R^{2}$ values vary considerably between the four stations. This may be explained by the fact that groundwater hydrodynamics probably triggers the entire Séchilienne landslide while the displacement velocity response depends on the damage level of the rock at the location of the displacement station. This interpretation is supported by the variability of the cumulative period, the shift factor, the weighting factor and the $R^{2}$ value, especially between G5 and the three other stations (Table 2).
The cumulative period and the shift factor deduced from the antecedent cumulative sum allow determining the response time of the Séchilienne landslide to rainfall events. Displacement stations located in the high motion zone show homogenous time delays with shift factors of 2-3 days. The average cumulative periods beyond which precipitation or $R_{\text {LRIW }}$ have no longer any influence on the landslide destabilisation are estimated at about 50 days for precipitation and

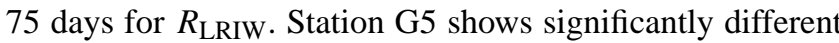
time delays and cumulative periods, whatever the precipitation or $R_{\text {LRIW }}$ data used. This difference can be explained by the low signal-to-noise ratio which makes the correlations difficult to interpret.

Concerning the A16 extensometer, regarding precipitation, $R^{2}$ is better for the recent short testing interval $(0.343)$ than for the former long interval of the sensitivity analysis (0.311). Conversely, regarding the recharge, $R^{2}$ is better for the former long interval (0.618) than for the recent short testing interval (0.586). This could be the consequence of a degradation of the near-surface rock mechanical properties of the Séchilienne landslide (as suggested by the displacement trend; Fig. 4), which makes the landslide more sensitive to precipitation events in the recent period.

Lastly, the best correlations from the sensitivity analysis suggest that infiltration structures could gather a large proportion of the flow (up to $68 \%$ for $\mathrm{SAWC}=45 \mathrm{~mm}$; NH4 LBCI $<0)$ with respect to their recharge surface area $(24 \%$; Table 5). If so, fractures can play an important role in the groundwater drainage from the massif towards the landslide aquifers. 
Acknowledgements. This research was funded by the SLAMS program (Séchilienne Land movement: Multidisciplinary Studies) of the National Research Agency (ANR). The meteorological data were provided by Météo France, LTHE, ONF and CEREMA Lyon. Aerial photographs and the digital elevation model were provided by IGN. Displacement data were supplied by CEREMA Lyon. The authors acknowledge the support of Jean-Pierre Duranthon and Marie-Aurélie Chanut from the CEREMA Lyon and Jean-Paul Laurent from the LTHE. Appreciation is also given to Eric Lucot for his kind advice on soil log interpretation, to Patrick Giraudoux for his support implementing bootstrap tests and to Pete Milmo for English and technical proof reading. Lastly, the authors thank the editor and the three anonymous referees for their insightful comments.

Edited by: N. Romano

\section{References}

Alexandris, S., Stricevic, R., and Petkovic, S.: Comparative analysis of reference evapotranspiration from the surface of rainfed grass in central Serbia, calculated with six empirical methods against the Penman-Monteith formula, European Water, 21/22, 17-28, 2008.

Alfonsi, P.: Relation entre les paramètres hydrologiques et la vitesse dans les glissements de terrains, Exemples de La Clapière et de Séchilienne, Revue Française de Géotechnique, 79, 3-12, 1997.

Alkaeed, O. A., Flores, C., Jinno, K., and Tsutsumi, A.: Comparison of Several Reference Evapotranspiration Methods for Itoshima Peninsula Area, Fukuoka, Japan, Memoirs of the Faculty of Engineering, Kyushu University, 66, 1-14, 2006.

Allen, R. E., Pereira, L. S., Raes, D., and Smith, M.: Crop evapotranspiration: guidelines for computing crop water requirements, FAO Irrigation and drainage paper 56, Food and Agriculture Organization of the United Nations, Rome, 1998.

Allen, R. G., Smith, M., Pereira, L. S., and Perrier, A.: An Update for the Definition of Reference Evapotranspiration, ICID Bull. Int. Commis. Irrig. Drain., 43, 1-34, 1994.

Almorox, J.: Estimating global solar radiation from common meteorological data in Aranjuez, Spain, Turk. J. Phys., 35, 53-64, 2011

Aragon, Y.: Séries temporelles avec R: Méthodes et cas, Springer Editions, Paris, 2011.

Baize, D. and Jabiol, B.: Guide pour la description des sols, 2nd Edn., Ed. Quae, Versailles, 2011.

Belle, P., Aunay, B., Bernardie, S., Grandjean, G., Ladouche, B., Mazué, R., and Join, J.-L.: The application of an innovative inverse model for understanding and predicting landslide movements (Salazie cirque landslides, Reunion Island), Landslides, 11, 343-355, doi:10.1007/s10346-013-0393-5, 2014.

Binet, S., Guglielmi, Y., Bertrand, C., and Mudry, J.: Unstable rock slope hydrogeology: insights from the large-scale study of western Argentera-Mercantour hillslopes (South-East France), Bulletin de la Société Géologique de France, 178, 159-168, doi:10.2113/gssgfbull.178.2.159, 2007a.

Binet, S., Mudry, J., Scavia, C., Campus, S., Bertrand, C., and Guglielmi, Y.: In situ characterization of flows in a fractured unstable slope, Geomorphology, 86, 193-203, doi:10.1016/j.geomorph.2006.08.013, 2007b.

Bogaard, T., Guglielmi, Y., Marc, V., Emblanch, C., Bertrand, C., and Mudry, J.: Hydrogeochemistry in landslide research: a review, Bulletin de la Société Géologique de France, 178, 113-126, doi:10.2113/gssgfbull.178.2.113, 2007.

Bogaard, T., Maharjan, L. D., Maquaire, O., Lissak, C., and Malet, J.-P.: Identification of Hydro-Meteorological Triggers for Villerville Coastal Landslide, in: Landslide Science and Practice, edited by: Margottini, C., Canuti, P., and Sassa, K., Springer, Berlin, Heidelberg, 141-145, available at: http://link.springer.com.biblioplanets.gate.inist.fr/chapter/10. 1007/978-3-642-31427-8_18 (last access: 12 June 2014), 2013.

Bonzanigo, L., Eberhardt, E., and Loew, S.: Long-term investigation of a deep-seated creeping landslide in crystalline rock, Part I. Geological and hydromechanical factors controlling the Campo Vallemaggia landslide, Can. Geotech. J., 44, 1157-1180, doi:10.1139/T07-043, 2007.

Bristow, K. L. and Campbell, G. S.: On the relationship between incoming solar radiation and daily maximum and minimum temperature, Agr. Forest Meteorol., 31, 159-166, doi:10.1016/01681923(84)90017-0, 1984.

Brocca, L., Ponziani, F., Moramarco, T., Melone, F., Berni, N., and Wagner, W.: Improving Landslide Forecasting Using ASCATDerived Soil Moisture Data: A Case Study of the Torgiovannetto Landslide in Central Italy, Remote Sensing, 4, 1232-1244, doi:10.3390/rs4051232, 2012.

Bruand, A., Duval, O., and Cousin, I.: Estimation des propriétés de rétention en eau des sols à partir de la base de données SOLHYDRO: Une première proposition combinant le type d'horizon, sa texture et sa densité apparente, Etude et Gestion des Sols, 11, 323-334, 2004.

Brückl, E. P.: Cause-Effect Models of Large Landslides, Nat. Hazards, 23, 291-314, doi:10.1023/A:1011160810423, 2001.

Canuti, P., Focardi, P., and Garzonio, C.: Correlation between rainfall and landslides, Bull. Eng. Geol. Environ., 32, 49-54, doi:10.1007/BF02594765, 1985.

Cappa, F., Guglielmi, Y., Soukatchoff, V. M., Mudry, J., Bertrand, C., and Charmoille, A.: Hydromechanical modeling of a large moving rock slope inferred from slope levelling coupled to spring long-term hydrochemical monitoring: example of the La Clapière landslide (Southern Alps, France), J. Hydrol., 291, 6790, doi:10.1016/j.jhydrol.2003.12.013, 2004.

Cappa, F., Guglielmi, Y., Viseur, S., and Garambois, S.: Deep fluids can facilitate rupture of slow-moving giant landslides as a result of stress transfer and frictional weakening, Geophys. Res. Lett., 41, 61-66, doi:10.1002/2013GL058566, 2014.

Cartier, G. and Pouget, P.: Corrélation entre la pluviométrie et les déplacements de pentes instables, in: 9th European conference on soil mechanics and foundation engineering, vol. 1, CRC Press, Dublin, available at: http://www.crcpress.com/product/ isbn/9789061917229 (last access: 2 April 2014), 1987.

Castellvi, F.: A new simple method for estimating monthly and daily solar radiation. Performance and comparison with other methods at Lleida (NE Spain); a semiarid climate, Theor. Appl. Climatol., 69, 231-238, doi:10.1007/s007040170028, 2001.

Chanut, M.-A., Vallet, A., Dubois, L., and Duranthon, J.-P.: Mouvement de versant de Séchilienne: relations entre déplacements de 
surface et précipitations - analyse statistique, in: Journées Aléa Gravitaire 2013, Grenoble, France, 2013.

Chernick, M. R.: Bootstrap methods: A guide for practitioners and researchers, Wiley-Interscience, Hoboken, NJ, 2008.

Cordeiro, C. and Neves, M.: The Bootstrap methodology in time series forecasting, in: COMPSTAT 2006 - Proceedings in Computational Statistics, Springer, Rome, Italy, 1067-1073, available at: http://www.springer.com.biblioplanets.gate.inist.fr/statistics/ computational+statistics/book/978-3-7908-1708-9 (last access: 12 June 2014), 2006.

Cowpertwait, P. S. P. and Metcalfe, A.: Introductory Time Series with R, Édition: 2009, Springer-Verlag New York Inc., Dordrecht, New York, 2009.

Crozier, M. J.: Landslides: Causes, consequences et environment, Croom Helm, London, Dover, NH, 1986.

Delmas, P., Cartier, G., and Pouget, G.: Méthodes d'analyse des risques liés aux glissements de terrain, Bulletin Liaison Laboratoire Ponts et Chaussées, 150/151, 29-38, 1987.

Diodato, N., Guerriero, L., Fiorillo, F., Esposito, L., Revellino, P., Grelle, G., and Guadagno, F. M.: Predicting Monthly Spring Discharges Using a Simple Statistical Model, Water Resour. Manage., 28, 969-978, doi:10.1007/s11269-014-0527-0, 2014.

Duranthon, J.-P., Effendiaz, L., Memier, M., and Previtali, I.: Apport des méthodes topographiques et topométriques au suivi du versant rocheux instable des ruines de Séchilienne, Association Francaise de Topographie, 94, 31-38, 2003.

Durville, J.-L., Kasperki, J., and Duranthon, J.-P.: The Séchilienne landslide: monitoring and kinematics, in: First Italian Workshop on Landslides, vol. 1, Napoli, Italia, 174-180, 2009.

Garel, E., Marc, V., Ruy, S., Cognard-Plancq, A.-L., Klotz, S., Emblanch, C., and Simler, R.: Large scale rainfall simulation to investigate infiltration processes in a small landslide under dry initial conditions: the Draix hillslope experiment, Hydrol. Process., 26, 2171-2186, 2012.

Gochis, D. and Cuenca, R.: Plant Water Use and Crop Curves for Hybrid Poplars, J. Irrig. Drain. Eng., 126, 206-214, doi:10.1061/(ASCE)0733-9437(2000)126:4(206), 2000.

Godt, J. W., Baum, R. L., and Chleborad, A. F.: Rainfall characteristics for shallow landsliding in Seattle, Washington, USA, Earth Surf. Proc. Land., 31, 97-110, doi:10.1002/esp.1237, 2006.

Guglielmi, Y., Vengeon, J. M., Bertrand, C., Mudry, J., Follacci, J. P.. and Giraud, A.: Hydrogeochemistry: an investigation tool to evaluate infiltration into large moving rock masses (case study of La Clapière and Séchilienne alpine landslides), Bull. Eng. Geol. Environ., 61, 311-324, 2002.

Guglielmi, Y., Cappa, F., and Binet, S.: Coupling between hydrogeology and deformation of mountainous rock slopes: Insights from La Clapière area (southern Alps, France), Comptes Rendus Geoscience, 337, 1154-1163, doi:10.1016/j.crte.2005.04.016, 2005.

Guzzetti, F., Peruccacci, S., Rossi, M., and Stark, C. P.: The rainfall intensity-duration control of shallow landslides and debris flows: an update, Landslides, 5, 3-17, doi:10.1007/s10346-007-0112-1, 2008.

Hargreaves, G. H. and Allen, R. G.: History and Evaluation of Hargreaves Evapotranspiration Equation, J. Irrig. Drain. Eng., 129, 53-63, doi:10.1061/(ASCE)0733-9437(2003)129:1(53), 2003.

Hargreaves, G. and Samani, Z.: Reference Crop Evapotranspiration from Temperature, Appl. Eng. Agr., 1, 96-99, 1985.
Helmstetter, A. and Garambois, S.: Seismic monitoring of Séchilienne rockslide (French Alps): Analysis of seismic signals and their correlation with rainfalls, J. Geophys. Res., 115, F03016, doi:10.1029/2009JF001532, 2010.

Hong, Y., Hiura, H., Shino, K., Sassa, K., Suemine, A., Fukuoka, H., and Wang, G.: The influence of intense rainfall on the activity of large-scale crystalline schist landslides in Shikoku Island, Japan, Landslides, 2, 97-105, doi:10.1007/s10346-004-0043-z, 2005.

Hou, L. G., Xiao, H. L., Si, J. H., Xiao, S. C., Zhou, M. X., and Yang, Y. G.: Evapotranspiration and crop coefficient of Populus euphratica Oliv forest during the growing season in the extreme arid region northwest China, Agr. Water Manage., 97, 351-356, doi:10.1016/j.agwat.2009.09.022, 2010.

Igbadun, H., Mahoo, H., Tarimo, A., and Salim, B.: Performance of Two Temperature-Based Reference Evapotranspiration Models in the Mkoji Sub-Catchment in Tanzania, Agricultural Engineering International: the CIGR Ejournal, VIII, aailable from: http://ecommons.library.cornell.edu/handle/1813/10573 (last access: 15 April 2014), 2006.

Itenfisu, D., Elliott, R. L., Allen, R. G., and Walter, I. A.: Comparison of Reference Evapotranspiration Calculations as Part of the ASCE Standardization Effort, J. Irrig. Drain. Eng., 129, 440448, doi:10.1061/(ASCE)0733-9437(2003)129:6(440), 2003.

Jacobson, P. M. Z.: Fundamentals of Atmospheric Modeling, Édition: 2, Cambridge University Press, Cambridge, UK, New York, 2005.

Jamagne, M., Bétrémieux, R., Bégon, J. C., and Mori, A.: Quelques données sur la variabilité dans le milieu naturel de la réserve en eau des sols, Bulletin Technique d'Information du Ministère de l'Agriculture, 324-325, 627-641, 1977.

Jensen, M. E., Burman, R. D., and Allen, R. G.: Evapotranspiration and irrigation water requirements: a manual, American Society of Civil Engineers, New York, 1990.

Lebrouc, V., Schwartz, S., Baillet, L., Jongmans, D., and Gamond, J. F.: Modeling permafrost extension in a rock slope since the Last Glacial Maximum: Application to the large Séchilienne landslide (French Alps), Geomorphology, 198, 189-200, doi:10.1016/j.geomorph.2013.06.001, 2013.

Le Roux, O., Jongmans, D., Kasperski, J., Schwartz, S., Potherat, P., Lebrouc, V., Lagabrielle, R., and Meric, O.: Deep geophysical investigation of the large Séchilienne landslide (Western Alps, France) and calibration with geological data, Eng. Geol., 120, 18-31, doi:10.1016/j.enggeo.2011.03.004, 2011.

López-Moreno, J. I., Hess, T. M., and White, S. M.: Estimation of reference evapotranspiration in a mountainous mediterranean site using the Penman-Monteith equation with limited meteorological data, Pirineos, 164, 7-31, 2009.

Lu, J., Sun, G., McNulty, S. G., and Amatya, D. M.: A comparison of six potential evapotranspiration methods for regional use in the Southeastern United States, J. Am. Water Resour. Assoc., 41, 621-633, doi:10.1111/j.1752-1688.2005.tb03759.x, 2005.

Madsen, H.: Time Series Analysis, 1st Edn., Chapman and Hall/CRC, Boca Raton, 2007.

Makkink, G.: Testing the Penman formula by means of lysimeters, J. Inst. Water Eng., 11, 277-288, 1957.

Malet, J. P., Maquaire, O., and Vanash, T. W.: Hydrological behaviour of earthflows developed in clay-shales: investigation, concept and modelling, The Occurrence and Mechanisms of 
Flows in Natural Slopes and Earthfills, Patron Editore, Bologna, 175-193, 2003.

Maquaire, O.: Effects of Groundwater on the VillervilleCricqueboeuf Landslides, Sixteen Year Survey (Calvados, France), in: 8th Landslides International symposium, Cardiff, 1005-1010, 2000.

Matichard, Y. and Pouget, P.: Pluviométrie et comportement de versants instables, in Landslides: proceedings of the fifth International Symposium on Landslides, Lausanne, Switzerland, 725730, 1988

McCuen, R. H.: Hydrologic analysis and design, Pearson Prentice Hall, Upper Saddle River, NJ, 2005.

Meric, O., Garambois, S., Jongmans, D., Wathelet, M., Chatelain, J. L., and Vengeon, J. M.: Application of geophysical methods for the investigation of the large gravitational mass movement of Séchilienne, France, Can. Geotech. J., 42, 1105-1115, doi:10.1139/t05-034, 2005.

Meric, O., Garambois, S., and Orengo, Y.: Large Gravitational Movement Monitoring Using a Spontaneous Potential Network, in: Proc. 19th Annual Symposium on the Application of Geophysics to Engineering and Environmental Problems, EEGS, Seattle, USA, 202-209, 2006.

Mudry, J. and Etievant, K.: Synthèse hydrogéologique du versant instable des Ruines de Séchilienne, Unpublished report, UMR Chrono-Environnement, University of Franche-Comté, Franche-Comté, 2007.

Musy, A. and Higy, C.: Hydrology: A Science of Nature, English Edn., CRC Press, Science Publishers, Boca Raton, FL, Enfield, NH, 2011.

Noverraz, F., Bonnard, C., Dupraz, H., and Huguenin, L.: Grands glissements de terrain et climat, VERSINCLIM - Comportement passé, présent et futur des grands versants instables subactifs en fonction de l'évolution climatique, et évolution en continu des mouvements en profondeur, Rapport final PNR31 (Programme National de Recherche), vdf Hochschulverlag AG an der ETH Zürich, Zürich, Switzerland, 1998.

Pachepsky, Y. and Rawls, W. J.: Development of pedotransfer functions in soil hydrology, Elsevier, Amsterdam, New York, 2004.

Patwardhan, A., Nieber, J., and Johns, E.: Effective Rainfall Estimation Methods, J. Irrig. Drain. Eng., 116, 182-193, doi:10.1061/(ASCE)0733-9437(1990)116:2(182), 1990.

Pisani, G., Castelli, M., and Scavia, C.: Hydrogeological model and hydraulic behaviour of a large landslide in the Italian Western Alps, Nat. Hazards Earth Syst. Sci., 10, 2391-2406, doi:10.5194/nhess-10-2391-2010, 2010.

Ponziani, F., Pandolfo, C., Stelluti, M., Berni, N., Brocca, L., and Moramarco, T.: Assessment of rainfall thresholds and soil moisture modeling for operational hydrogeological risk prevention in the Umbria region (central Italy), Landslides, 9, 229-237, doi:10.1007/s 10346-011-0287-3, 2012.

Priestley, C. H. B. and Taylor, R. J.: On the Assessment of Surface Heat Flux and Evaporation Using Large-Scale Parameters, Mon. Weather Rev., 100, 81-92, doi:10.1175/15200493(1972)100<0081:OTAOSH>2.3.CO;2, 1972.

Prokešová, R., Medved'ová, A., Tábořík, P., and Snopková, Z.: Towards hydrological triggering mechanisms of large deep-seated landslides, Landslides, 10, 239-254, doi:10.1007/s10346-0120330-z, 2013.
Rochet, L., Giraud, A., Antoine, P., and Évrard, H.: La déformation du versant sud du Mont-Sec dans le secteur des ruines de Séchilienne (Isère), Bull. Int. Assoc. Eng. Geol., 50, 75-87, doi:10.1007/BF02594959, 1994.

Rutqvist, J. and Stephansson, O.: The role of hydromechanical coupling in fractured rock engineering, Hydrogeol. J., 11, 7-40, doi:10.1007/s10040-002-0241-5, 2003.

Shahidian, S., Serralheiro, R., Serrano, J., Teixeira, J., Haie, N., and Santos, F.: Hargreaves and Other Reduced-Set Methods for Calculating Evapotranspiration, in: Evapotranspiration - Remote Sensing and Modeling, edited by: Irmak, A., InTech, Rijeka, Croatia, 60-80, 2012.

Sivaprakasam, S., Murugappan, A., and Mohan, S.: Modified Hargreaves equation for estimation of ETo in a Hot and Humid Location in Tamilnadu State, India, Int. J. Eng. Sci. Technol., 3, 592-600, 2011.

Tabari, H. and Talaee, P. H.: Local Calibration of the Hargreaves and Priestley-Taylor Equations for Estimating Reference Evapotranspiration in Arid and Cold Climates of Iran Based on the Penman-Monteith Model, J. Hydrol. Eng., 16, 837-845, doi:10.1061/(ASCE)HE.1943-5584.0000366, 2011.

Tabari, H., Grismer, M. E., and Trajkovic, S.: Comparative analysis of 31 reference evapotranspiration methods under humid conditions, Irrig. Science, 31, 107-117, doi:10.1007/s00271-0110295-z, 2013.

Trajkovic, S.: Temperature-Based Approaches for Estimating Reference Evapotranspiration, J. Irrig. Drain. Eng., 131, 316-323, doi:10.1061/(ASCE)0733-9437(2005)131:4(316), 2005.

Trajkovic, S.: Hargreaves versus Penman-Monteith under Humid Conditions, J. Irrig. Drain. Eng., 133, 38-42, doi:10.1061/(ASCE)0733-9437(2007)133:1(38), 2007.

Trajkovic, S. and Stojnic, V.: Effect of wind speed on accuracy of Turc method in a humid climate, Facta universitatis - series: Architecture and Civil Engineering, 5, 107-113, doi:10.2298/FUACE0702107T, 2007.

Turc, L.: Evaluation des besoins en eau d'irrigation, évapotranspiration potentielle, formule simplifiée et mise à jour, Annales Agronomiques, 12, 13-49, 1961.

Van Asch, T. W. J., Buma, J., and van Beek, L. P.: A view on some hydrological triggering systems in landslides, Geomorphology, 30, 25-32, doi:10.1016/S0169-555X(99)00042-2, 1999.

Vengeon, J. M.: Déformation et rupture des versants en terrain métamorphique anisotrope: Apport de l'étude des Ruines de Séchilienne, PhD thesis, Université Joseph Fourier I, 3 November 1998, Grenoble, 1998.

Verstraeten, W. W., Muys, B., Feyen, J., Veroustraete, F., Minnaert, M., Meiresonne, L., and De Schrijver, A.: Comparative analysis of the actual evapotranspiration of Flemish forest and cropland, using the soil water balance model WAVE, Hydrol. Earth Syst. Sci., 9, 225-241, doi:10.5194/hess-9-225-2005, 2005.

Yoder, R. E., Odhiambo, L. O., and Wright, W. C.: Evaluation of methods for estimating daily reference crop evapotranspiration at a site in the humid Southeast United States, Appl. Eng. Agr., 21, 197-202, 2005.

Zêzere, J. L., Trigo, R. M., and Trigo, I. F.: Shallow and deep landslides induced by rainfall in the Lisbon region (Portugal): assessment of relationships with the North Atlantic Oscillation, Nat. Hazards Earth Syst. Sci., 5, 331-344, doi:10.5194/nhess-5-3312005, 2005. 